\title{
Slurry-phase ethylene polymerisation using group 4 ansa-bridged permethylindenyl complexes supported on polymethylaluminoxane
}

\author{
Jessica V. Lamb, Joseph C. Abell, Jack E. McLaren, Jean-Charles Buffet, Zoë R. Turner and \\ Dermot O'Hare*
}

\begin{abstract}
Chemistry Research Laboratory, Department of Chemistry, University of Oxford, 12 Mansfield Road, OX1 3TA
\end{abstract} Oxford, UK. E-mail: dermot.ohare@chem.ox.ac.uk

\begin{abstract}
Five new group 4 ansa-bridged permethylindenyl complexes with either a dimethylsilane bridge or a tetramethyldisilane bridge have been synthesised and fully characterised. These complexes were supported on a hydrocarbon insoluble polymethylaluminoxane (sMAO) and the slurry-phase ethylene polymerisation performance was investigated. The highest activity was achieved using ${ }^{\mathrm{Me}_{2}} \mathrm{SB}\left(\mathrm{Cp}^{\mathrm{Me}}, \mathrm{I}^{*}\right) \mathrm{Zr}\left(\mathrm{CH}_{2} \mathrm{SiMe}_{3}\right)_{2}\left(8042 \mathrm{~kg}_{\mathrm{PE}} \mathrm{mol}_{\mathrm{Zr}}{ }^{-1} \mathrm{~h}^{-1} \mathrm{bar}^{-1}\right.$ at $\left.60{ }^{\circ} \mathrm{C}\right)$ but a decrease in activity was observed with an increase in the length of the bridge. DSC analysis of the polymers revealed the production of HDPE with minimal branching and defects, while SEM showed the production of polymer particles with commercially desirable uniform, 'popcorn', morphology. GPC analysis showed the production of polyethylenes with $M_{\mathrm{w}}<$ $570 \mathrm{~kg} \mathrm{~mol}^{-1}$ at $80^{\circ} \mathrm{C}$. In addition, ${ }^{\mathrm{Me}_{2}} \mathrm{SB}\left(\mathrm{Cp}, \mathrm{I}^{*}\right) \mathrm{Zr}\left(\mathrm{CH}_{2} \mathrm{SiMe}_{3}\right)_{2}$ was immobilised on MAO modified layered double hydroxide (LDHMAO). The slurry-phase polymerisation activity of $\mathrm{Me}_{2} \mathrm{SB}\left(\mathrm{Cp}, \mathrm{I}^{*}\right) \mathrm{Zr}\left(\mathrm{CH}_{2} \mathrm{SiMe}_{3}\right)_{2}$ on this support system was similar to the sMAO support, however the polymer morphology was much less uniform.
\end{abstract}

\section{Keywords}

Zirconocene, permethylindenyl, polymerisation, ethylene, layered double hydroxide

\section{Introduction}

Metallocene catalysts provide a multitude of possibilities for synthesising and controlling the structure and properties of polymers.[1-3] The single-site nature of metallocene catalysts leads to the formation of polymers with unimodal molecular weight distributions, [4] while ansa-bridges between the two cyclopentadienyl substituents can be employed to prevent ligand rotation and enforce complex rigidity.[5] Single atom silicon or carbon, and two atom carbon bridged metallocenes have been widely explored as catalysts for olefin polymerisation.[1, 5- 
10] However, tetramethyldisilylene-bridged zirconocenes with the potential to combine the electronic and steric properties of both silyl and ethylene bridging groups have been far less

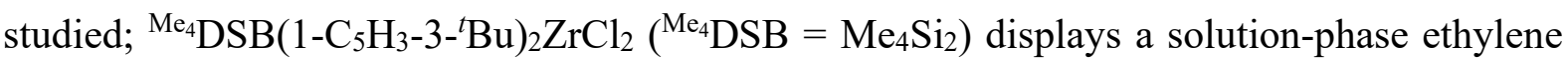
polymerisation activity of $2090 \mathrm{~kg}_{\mathrm{PE}} \mathrm{molzr}^{-1} \mathrm{~h}^{-1} \mathrm{bar}^{-1}$ at $30{ }^{\circ} \mathrm{C}$ with methylaluminoxane (MAO) co-catalyst and 1 bar ethylene.[11]

Metallocene catalysts can be immobilised onto solid supports utilising the principles of surface organometallic chemistry,[12-19] in which the oxygen surface sites of the support act as anionic X-type ligands that covalently bond to the metal centre.[13-15, 20] The goal of immobilising $\alpha$-olefin polymerisation catalysts is to preserve the advantages of homogeneous polymerisation, such as high activities and selectivities,[1, 21, 22] while improving polymer morphology via the templating effect of the solid support and reducing reactor fouling.[23-25] Many different types of solid support can be used for the immobilisation of metallocene catalysts, including highly Lewis acidic species such as $\mathrm{MgCl}_{2}, \mathrm{SiO}_{2}-\mathrm{Al}_{2} \mathrm{O}_{3}$ and $\mathrm{Al}_{2} \mathrm{O}_{3}$, and neutral or moderately Lewis acidic species such as $\mathrm{SiO}_{2}$ and $\mathrm{MgO} .[13,26,27]$ Brønstead acidic species have also been shown to be efficient supports for the grafting of zirconocene catalyst precursors.[13, 28-30] These supports include highly Brønsted "super-acidic" sulfated metal oxides such as alumina, titania and zirconia.[28]

Solid polymethylaluminoxane (sMAO) is an insoluble form of oligomeric MAO that has recently been exploited as a solid support for metallocene pre-catalysts in slurry-phase olefin polymerisation.[7, 31-33] It is an oligomeric product of the incomplete hydrolysis of $\mathrm{AlMe}_{3}$ (TMA) and consists of (AlMeO) $)_{n}$, where $n=6-30$ monomer units.[34] The key advantage of sMAO as a metallocene support is that it can act as a bifunctional support and activator without further modification. We recently reported a range of unsymmetrical ansabridged permethylindenyl compounds of the type ${ }^{\mathrm{Me}_{2}} \mathrm{SB}\left(\mathrm{Cp}^{\mathrm{R}}, \mathrm{I}^{*}\right) \mathrm{ZrX} \mathrm{X}_{2}\left(\left\{\left(\eta^{5}-\mathrm{C}_{9} \mathrm{Me}_{6}\right) \mathrm{Me}_{2} \mathrm{Si}\left(\eta^{5}-\right.\right.\right.$ $\left.\left.\mathrm{C}_{5} \mathrm{H}_{3} \mathrm{R}\right)\right\} \mathrm{ZrX}_{2} ; \mathrm{R}=\mathrm{H}, \mathrm{Me}$ and ${ }^{n} \mathrm{Bu} ; \mathrm{X}=\mathrm{Cl}, \mathrm{Br}, \mathrm{Me}$ and $\left.\mathrm{CH}_{2} \mathrm{Ph}\right)$ and ${ }^{\mathrm{R}_{2}} \mathrm{SB}\left({ }^{\left(\mathrm{Bu}_{2}\right.} \mathrm{Flu}, \mathrm{I}^{*}\right) \mathrm{ZrX}_{2}\left(\left\{\left(\eta^{5}-\right.\right.\right.$ $\left.\left.\mathrm{C}_{9} \mathrm{Me}_{6}\right) \mathrm{R}_{2} \mathrm{Si}\left(\eta^{5}-2,9-{ }^{t} \mathrm{Bu}_{-} \mathrm{C}_{13} \mathrm{H}_{6}\right)\right\} \mathrm{ZrX}_{2},\left\{\left(\eta^{5}-\mathrm{I}^{*}\right) \mathrm{R}_{2} \mathrm{Si}\left(\eta^{5}-2,{ }^{-}{ }^{t} \mathrm{Bu}-\mathrm{Flu}\right)\right\} \mathrm{ZrX}_{2} ; \mathrm{R}=\mathrm{Me}, \mathrm{Et}$ and $\mathrm{X}=$ $\mathrm{Cl}$ and $\mathrm{Br}$ ) for slurry-phase ethylene polymerisation (Chart 1).[7, 35, 36] When immobilised on sMAO the species showed activities up to $83 \%$ higher than an industrial standard, $\left(\mathrm{Cp}^{n \mathrm{Bu}}\right)_{2} \mathrm{ZrCl}_{2}$, under the same polymerisation conditions.[35] 


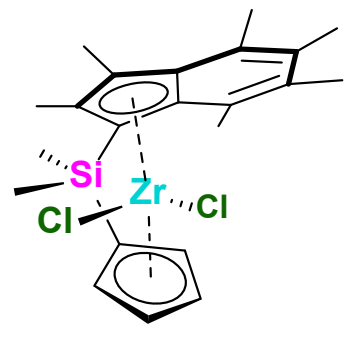

A

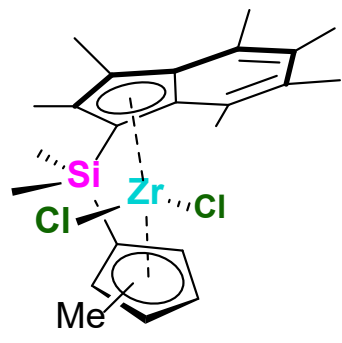

B

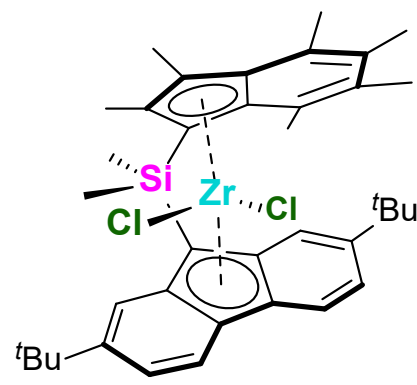

C

Chart 1. Example of previously reported group 4 permethylindenyl complexes ${ }^{\mathrm{Me}_{2}} \mathrm{SB}\left(\mathrm{Cp}, \mathrm{I}^{*}\right) \mathrm{ZrCl}_{2}(\mathbf{A}),[36]{ }^{\mathrm{Me}}{ }_{2} \mathrm{SB}\left(\mathrm{Cp}^{\mathrm{Me}}, \mathrm{I}^{*}\right) \mathrm{ZrCl}_{2}$ (B) [36] and ${ }^{\mathrm{Me}_{2}} \mathrm{SB}\left({ }^{t \mathrm{Bu}_{2}} \mathrm{Flu} \mathrm{I}^{*}\right) \mathrm{ZrCl}_{2}$ (C).[7]

\section{Results and Discussion}

\subsection{Synthesis of ${ }^{\mathrm{Me}_{4}} \mathrm{DSB}\left(\mathrm{Cp}, \mathrm{I}^{*}\right) \mathrm{Li}_{2}$ and ${ }^{\mathrm{Me}_{4}} \mathrm{DSB}\left({ }^{\mathrm{IBu}}{ }_{2} \mathbf{F l u}, \mathrm{I}^{*}\right) \mathrm{Li}_{2}$ ligands}

Ind* $\left(\mathrm{SiMe}_{2}\right)_{2} \mathrm{Cl}$ was synthesised in an analogous fashion to previously reported Ind*SiMe $2 \mathrm{Cl} ;[36]$ hexamethylindene $\left(\operatorname{Ind}^{\#} \mathrm{H}\right)$ was deprotonated with 1.1 equivalents of $n$-butyllithium and the product added to 3.0 equivalents of $\mathrm{Me}_{4} \mathrm{Si}_{2} \mathrm{Cl}_{2}$. Following workup, Ind* $\left(\mathrm{SiMe}_{2}\right)_{2} \mathrm{Cl}$ was isolated as a pale yellow solid in $70 \%$ yield. The ${ }^{1} \mathrm{H}$ NMR spectrum shows four singlets between -0.21 and $0.36 \mathrm{ppm}$ corresponding to the protons of the silyl bridge methyl groups, six singlets between 2.10 and 2.49 ppm corresponding to the methyl groups of the permethylindenyl ligand and a resonance at $3.55 \mathrm{ppm}$ corresponding to the allylic proton of the indenyl ring (Figure S1).

Analogous to the synthesis of ${ }^{\mathrm{Me}_{2}} \mathrm{SB}\left(\mathrm{Cp}, \mathrm{I}^{*}\right) \mathrm{Li}_{2},[36]$ dilithium salts ${ }^{\mathrm{Me}_{4}} \mathrm{DSB}\left(\mathrm{Cp}, \mathrm{I}^{*}\right) \mathrm{Li}_{2}$ $\left(\left\{\left(\eta^{5}-\mathrm{C}_{9} \mathrm{Me}_{6}\right) \mathrm{Me}_{4} \mathrm{Si}_{2}\left(\eta^{5}-\mathrm{C}_{5} \mathrm{H}_{5}\right)\right\} \mathrm{Li}_{2}\right)$ and $\left.{ }^{\mathrm{Me}_{4}} \mathrm{DSB}{ }^{t \mathrm{Bu}_{2}} \mathrm{Flu}_{1} \mathrm{I}^{*}\right) \mathrm{Li}_{2}$ were prepared by the reaction of equimolar quantities of $\mathrm{Ind}^{*}\left(\mathrm{SiMe}_{2}\right)_{2} \mathrm{Cl}$ and $\mathrm{LiCp}$ or $\mathrm{Li}\left({ }^{t \mathrm{Bu}_{2}} \mathrm{Flu}\right)$ respectively, followed by deprotonation with two equivalents of ${ }^{n} \mathrm{BuLi}$ (Scheme 1). Following work up, ${ }^{\mathrm{Me}_{4}}{ }_{\mathrm{DSB}}\left(\mathrm{Cp}, \mathrm{I}^{*}\right) \mathrm{Li}_{2}$ and ${ }^{\mathrm{Me}_{4}} \mathrm{DSB}\left({ }^{t \mathrm{Bu}_{2}} \mathrm{Flu}, \mathrm{I}^{*}\right) \mathrm{Li}_{2} .\left(\mathrm{Et}_{2} \mathrm{O}\right)_{1.5}$ were obtained in 78 and $19 \%$ yield respectively. The ${ }^{1} \mathrm{H}$ NMR spectra show six singlets between 2.24 and 3.06 ppm corresponding to the methyl groups on the indenyl ring and two singlets at 0.83 and $1.28 \mathrm{ppm}$ corresponding to the methyl groups on the disilylene bridging moiety (Figures S3 and S5). The ${ }^{1} \mathrm{H}$ NMR spectrum of ${ }^{\mathrm{Me}_{4}} \mathrm{DSB}\left(\mathrm{Cp}, \mathrm{I}^{*}\right) \mathrm{Li}_{2}$ also shows multiplets at 6.27 and $6.56 \mathrm{ppm}$ corresponding to the protons on the cyclopentadienyl ring, while ${ }^{\mathrm{Me}_{4}} \mathrm{DSB}\left({ }^{t \mathrm{Bu}_{2}} \mathrm{Flu}_{,} \mathrm{I}^{*}\right) \mathrm{Li}_{2}$ shows a singlet at $1.64 \mathrm{ppm}$ and three resonances at $7.12,8.47$ and $8.50 \mathrm{ppm}$ corresponding to the tert-butyl and aromatic protons of the ${ }^{t \mathrm{Bu}_{2}} \mathrm{Flu}$ ligand. 


\subsection{Synthesis of ${ }^{\mathrm{Me}}{ }_{4} \mathrm{DSB}\left(\mathrm{Cp}, \mathrm{I}^{*}\right) \mathrm{ZrCl}_{2}(1)$ and ${ }^{\mathrm{Me}}{ }_{4} \mathrm{DSB}\left({ }^{\left(\mathrm{Bu}_{2}\right.} \mathrm{Flu}_{,} \mathrm{I}^{*}\right) \mathrm{ZrCl}_{2}$ (2)}

Equimolar mixtures of dilithium salts ${ }^{\mathrm{Me}}{ }_{4} \mathrm{DSB}\left(\mathrm{Cp}, \mathrm{I}^{*}\right) \mathrm{Li}_{2}$ or $\left.{ }^{\mathrm{Me}}{ }_{4} \mathrm{DSB}^{\mathrm{tBu}}{ }^{\mathrm{B}} \mathrm{Flu}_{1} \mathrm{I}^{*}\right) \mathrm{Li}_{2}\left(\mathrm{Et}_{2} \mathrm{O}\right)_{1.5}$ and $\mathrm{ZrCl}_{4}$ were stirred in benzene for 16 hours at room temperature (Scheme 1). Following work up, ${ }^{\mathrm{Me}_{4}} \mathrm{DSB}\left(\mathrm{Cp}, \mathrm{I}^{*}\right) \mathrm{ZrCl}_{2}$ (1) and ${ }^{\mathrm{Me}_{4}} \mathrm{DSB}\left({ }^{t \mathrm{Bu}_{2}} \mathrm{Flu} \mathrm{I}^{*}\right) \mathrm{ZrCl}_{2}$ (2) were isolated as orange solids in 13 and $52 \%$ yield respectively. The ${ }^{1} \mathrm{H}$ NMR spectra of $\mathbf{1}$ and 2 show six singlets of equal intensity between 1.98 and $2.84 \mathrm{ppm}$ corresponding to the methyl groups of the indenyl ring and four singlets between 0.35 and $0.86 \mathrm{ppm}$ corresponding to the methyl groups of the disilyl bridge (Figures S7 and S9). The ${ }^{1} \mathrm{H}$ NMR spectrum of $\mathbf{1}$ also shows multiplet resonances corresponding to the protons on the cyclopentadienyl ring between 5.67 and $6.84 \mathrm{ppm}$, while 2 shows the tert-butyl groups of the fluorenyl ligand as singlets at 1.32 and $1.40 \mathrm{ppm}$ and the three aromatic proton environments of the fluorenyl ligand as doublets of doublets at 7.40 and $7.59 \mathrm{ppm}$, singlets at 7.69 and $7.62 \mathrm{ppm}$ and doublets at 7.70 and $7.86 \mathrm{ppm}$.

(a)
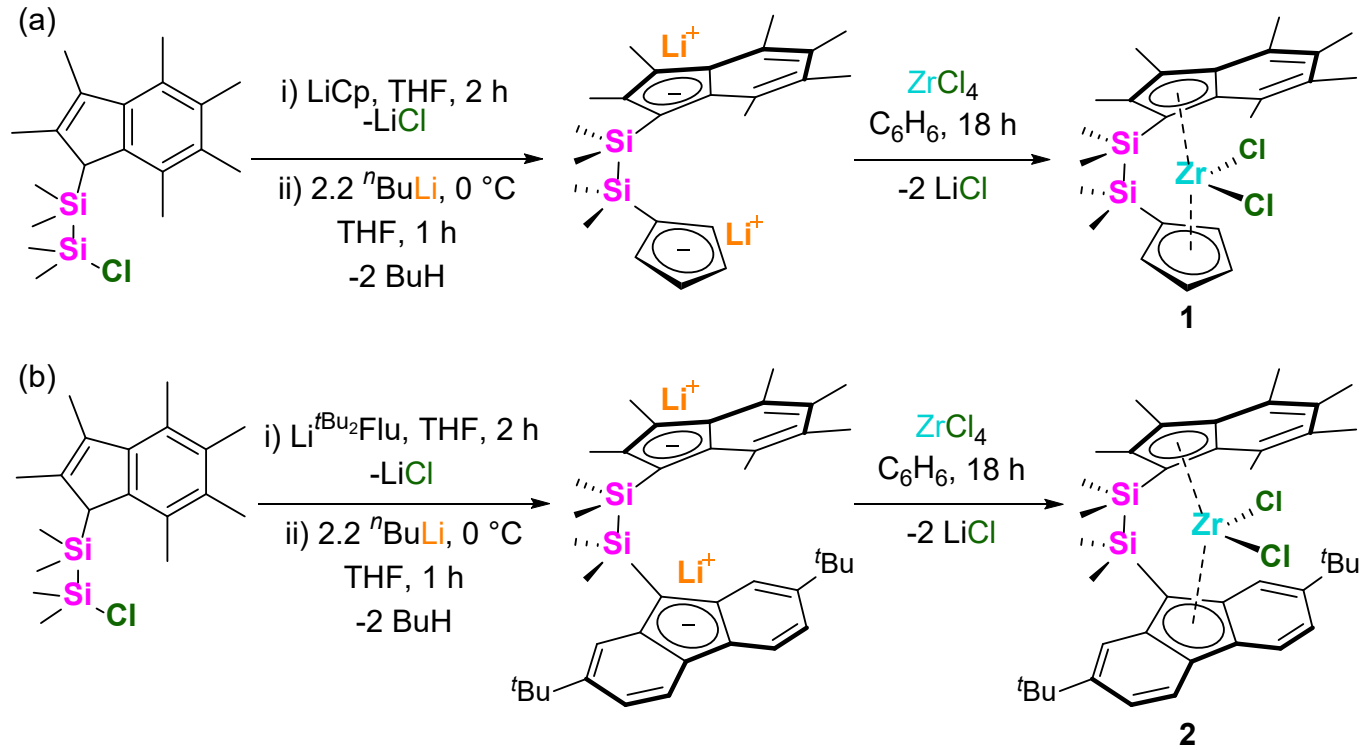

Scheme 1. Synthesis of ${ }^{\mathrm{Me}_{4}} \mathrm{DSB}\left(\mathrm{Cp}, \mathrm{I}^{*}\right) \mathrm{ZrCl}_{2}$ (1) and ${ }^{\mathrm{Me}_{4}} \mathrm{DSB}\left({ }^{t \mathrm{Bu}_{2}} \mathrm{Flu}_{,} \mathrm{I}^{*}\right) \mathrm{ZrCl}_{2}$ (2).

Crystals of 2 suitable for a single crystal X-ray diffraction study were grown from pentane at $-34{ }^{\circ} \mathrm{C}$. The solid-state molecular structure is depicted in Figure 1, with selected bond lengths and angles presented in Table 1. Complex 2 displays a similar Zr-Flu $\mathrm{u}_{\text {cent }}$ distance to the corresponding mono-silyl bridged species ${ }^{\mathrm{Me}_{2}} \mathrm{SB}\left({ }^{\mathrm{tBu}}{ }_{2} \mathrm{Flu}, \mathrm{I}^{*}\right) \mathrm{ZrCl}_{2}(2.3144$ and $2.300 \AA$ respectively),[7] however possesses a slightly longer $\mathrm{Zr}$-Ind cent $_{\text {distance }}(2.2540$ and $2.227 \AA$ respectively) due to the longer length of the bridge. Complex 2 also displays a longer Zr-Ind $\mathrm{Ient}_{\mathrm{c}}$ distance than rac-EBI* $\mathrm{ZrCl}_{2}$ and meso-EBI* $\mathrm{ZrCl}_{2}$ (average $\mathrm{Zr}$-Ind $\mathrm{Inent}_{\text {of }} 2.240$ and $2.246 \AA$ respectively)[8] and longer $\mathrm{Zr}$-centroid distances than meso- ${ }^{-{ }^{-} e_{4}} \mathrm{DSB}\left(1-\mathrm{C}_{5} \mathrm{H}_{3}-3-{ }^{t} \mathrm{Bu}\right)_{2} \mathrm{ZrCl}_{2}$ and 
rac $-{ }^{\mathrm{Me}_{4}} \mathrm{~EB}\left(1-\mathrm{C}_{5} \mathrm{H}_{3}-3-{ }^{t} \mathrm{Bu}\right){ }_{2} \mathrm{ZrCl}_{2}$ (average $\mathrm{Zr}-\mathrm{Cp}^{\mathrm{R}}$ cent of 2.238 and $2.227 \AA$ ).[11, 37] 2 shows a larger angle about the metal centre $(\delta)$ and smaller ring tilt angle $(\alpha)$ than ${ }^{\mathrm{Me}_{2}} \mathrm{SB}\left({ }^{t \mathrm{Bu}_{2}} \mathrm{Flu}, \mathrm{I}^{*}\right) \mathrm{ZrCl}_{2}$ $\left(\delta=139.70^{\circ}\right.$ and $131.0^{\circ} ; \alpha=54.91^{\circ}$ and $\left.62.04^{\circ}\right)$, implying that the two atom disilyl bridge causes a lesser degree of ring tilt and a less open and less available metal centre than the one atom silyl bridge. The $\alpha$ and $\delta$ angles of $\mathbf{2}$ are larger than the values reported for meso- ${ }^{\mathrm{Me}_{4}} \mathrm{DSB}\left(3-\mathrm{SiMe}_{3}-\mathrm{Ind}\right)_{2} \mathrm{ZrCl}_{2} \quad\left(\alpha=47.8^{\circ}\right.$ and $\left.\delta=134.6^{\circ}\right)$ suggesting that the unsymmetrical system causes a larger degree of ring tilt.[38] The C-Si-Si angles of the bridge for $2\left(103.05^{\circ}\right.$ and $\left.102.10^{\circ}\right)$ are comparable to those recorded for meso- ${ }^{\mathrm{Me}_{4}} \mathrm{DSB}\left(3-\mathrm{SiMe}_{3}-\mathrm{Ind}\right)_{2} \mathrm{ZrCl}_{2}\left(103.30^{\circ}\right.$ and $\left.102.69^{\circ}\right)$.[38] However, the C-Si-Si angles for 2 are larger than the C-Si-C angle recorded for $\left.{ }^{\mathrm{Me}_{2}} \mathrm{SB}^{t \mathrm{Bu}_{2}} \mathrm{Flu}, \mathrm{I}^{*}\right) \mathrm{ZrCl}_{2}\left(95.61^{\circ}\right)$, implying a smaller degree of strain in the bridge.[7]

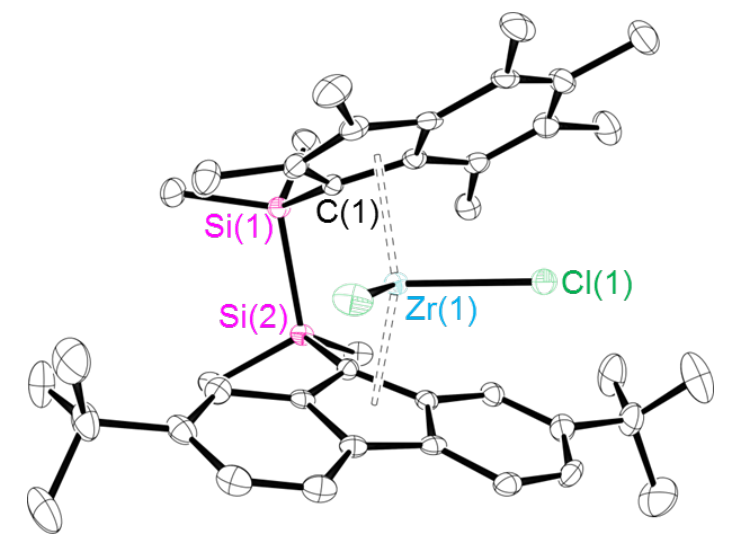

Figure 1. Solid-state molecular structure of ${ }^{\mathrm{Me}_{4}} \mathrm{DSB}\left({ }^{t \mathrm{Bu}_{2}} \mathrm{Flu}, \mathrm{I}^{*}\right) \mathrm{ZrCl}_{2}$ (2). H atoms omitted for clarity. Thermal ellipsoids drawn at $30 \%$ probability. 
Table 1. Selected bond lengths $(\AA)$ and angles $\left(^{\circ}\right)$ for $\mathbf{2}, \mathbf{A}$ and $\mathbf{5}$.

\begin{tabular}{|c|c|c|c|c|c|}
\hline & Complex & $\operatorname{Zr}(1)-C_{p^{R}}^{R_{\text {cent }}}$ & Zr(1)-Ind cent & $\alpha$ & $\bar{\delta}$ \\
\hline \multirow[t]{5}{*}{2} & $\mathrm{Me}_{4} \mathrm{DSB}\left({ }^{t \mathrm{Bu}_{2}} \mathrm{Flu}, \mathrm{I}^{*}\right) \mathrm{ZrCl}_{2}$ & $2.3347(1)^{\mathrm{a}}$ & $2.2714(1)$ & 54.91 & 139.70 \\
\hline & ${ }^{\mathrm{Me}_{2}} \mathrm{SB}\left({ }^{t \mathrm{Bu}_{2}} \mathrm{Flu}, \mathrm{I}^{*}\right) \mathrm{ZrCl}_{2}$ [7] & $2.300^{\mathrm{a}}$ & 2.227 & 62.04 & 131.0 \\
\hline & meso- $-{ }^{\mathrm{Me}_{4}} \mathrm{DSB}\left(3-\mathrm{SiMe}_{3}-\mathrm{Ind}\right)_{2} \mathrm{ZrCl}_{2}[38]$ & - & $2.261^{\mathrm{b}}$ & 47.8 & 134.64 \\
\hline & rac-EBI* $\mathrm{ZrCl}_{2}[8]$ & - & $2.240^{\mathrm{b}}$ & 57.2 & 129.4 \\
\hline & meso-EBI* $\mathrm{ZrCl}_{2}[8]$ & 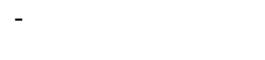 & $2.246^{\mathrm{b}}$ & 56.9 & 128.7 \\
\hline $\mathbf{A}$ & $\mathrm{Me}_{2} \mathrm{SB}\left(\mathrm{Cp}, \mathrm{I}^{*}\right) \mathrm{ZrCl}_{2}[35]$ & $2.2076(1)$ & $2.2244(1)$ & 60.19 & 126.37 \\
\hline \multirow[t]{2}{*}{5} & ${ }^{\mathrm{Me}_{2}} \mathrm{SB}\left(\mathrm{Cp}, \mathrm{I}^{*}\right) \mathrm{ZrCl}\left(\mathrm{O}-2,6-{ }^{i} \mathrm{Pr}-\mathrm{C}_{6} \mathrm{H}_{3}\right)$ & $2.2070(1)$ & $2.2462(1)$ & 59.62 & 125.29 \\
\hline & $\mathrm{Me}_{2} \mathrm{SB}\left(\mathrm{Cp}, \mathrm{I}^{*}\right) \mathrm{ZrCl}\left(\mathrm{O}-2,6-\mathrm{Me}-\mathrm{C}_{6} \mathrm{H}_{3}\right)[36]$ & $2.2201(1)$ & $2.2504(1)$ & 60.88 & 126.90 \\
\hline
\end{tabular}

(a) Zr-Flu cent $_{\text {distance and (b) average } \mathrm{Zr}-\text { Ind }_{\text {cent }} \text { distance. }}$

\subsection{Synthesis of ${ }^{\mathrm{Me}_{2}} \mathrm{SB}\left(\mathrm{Cp}^{\mathrm{R}}, \mathrm{I}^{*}\right) \mathrm{ZrR}_{2}{ }_{2}\left(\mathrm{R}=\mathrm{H}\right.$ and $\mathrm{Me}$; $\mathrm{R}^{\prime}=\mathrm{CH}_{2} \mathrm{SiMe}_{3}$ and O-2,6- $\left.{ }^{i} \mathrm{Pr}-\mathrm{C}_{6} \mathrm{H}_{3}\right)$} $\mathrm{Me}_{2} \mathrm{SB}\left(\mathrm{Cp}, \mathrm{I}^{*}\right) \mathrm{ZrCl}_{2}(\mathbf{A})$ and ${ }^{\mathrm{Me}_{2}} \mathrm{SB}\left(\mathrm{Cp}^{\mathrm{Me}}, \mathrm{I}^{*}\right) \mathrm{ZrCl}_{2}$ (B) were synthesised according to a literature procedure;[36] as reported, $\mathbf{B}$ was obtained as a 60:40 mixtures of two isomers with the methyl group at the gamma positions of the $\mathrm{Cp}$ ring. The reaction of $\mathbf{A}$ and $\mathbf{B}$ with 2.5 equivalents of $\mathrm{LiCH}_{2} \mathrm{SiMe}_{3}$ afforded ${ }^{\mathrm{Me}_{2}} \mathrm{SB}\left(\mathrm{Cp}, \mathrm{I}^{*}\right) \mathrm{Zr}\left(\mathrm{CH}_{2} \mathrm{SiMe}_{3}\right)_{2}$ (3) and ${ }^{\mathrm{Me}_{2}} \mathrm{SB}\left(\mathrm{Cp}^{\mathrm{Me}}, \mathrm{I}^{*}\right) \mathrm{Zr}\left(\mathrm{CH}_{2} \mathrm{SiMe}_{3}\right)_{2}$ (4) as yellow solids in 12 and 53\% yield respectively (Equation 1). The ${ }^{1} \mathrm{H}$ NMR spectra of 3 and 4 showed cyclopentadienyl, permethylindenyl methyl and silyl bridge methyl resonances at 4.94-6.90, 1.83-2.90 and 0.62-0.69 ppm respectively (Figures S11 and S13). The ${ }^{1} \mathrm{H}$ NMR spectra also showed singlet resonances at $-0.02-0.21 \mathrm{ppm}$ and doublet resonances at -2.49 $0.69 \mathrm{ppm}$ corresponding to the methyl groups and diastereotopic $\mathrm{CH}_{2}$ protons of the neosilyl ligand respectively. The ${ }^{1} \mathrm{H}$ NMR spectrum of 4 confirmed that the 60:40 mixture of isomers in the parent dichloride complex, where the methyl substituent lies in the $\gamma$-position of the cyclopentadienyl ring furthest and nearest to the permethylindenyl group respectively, is maintained in the product. 


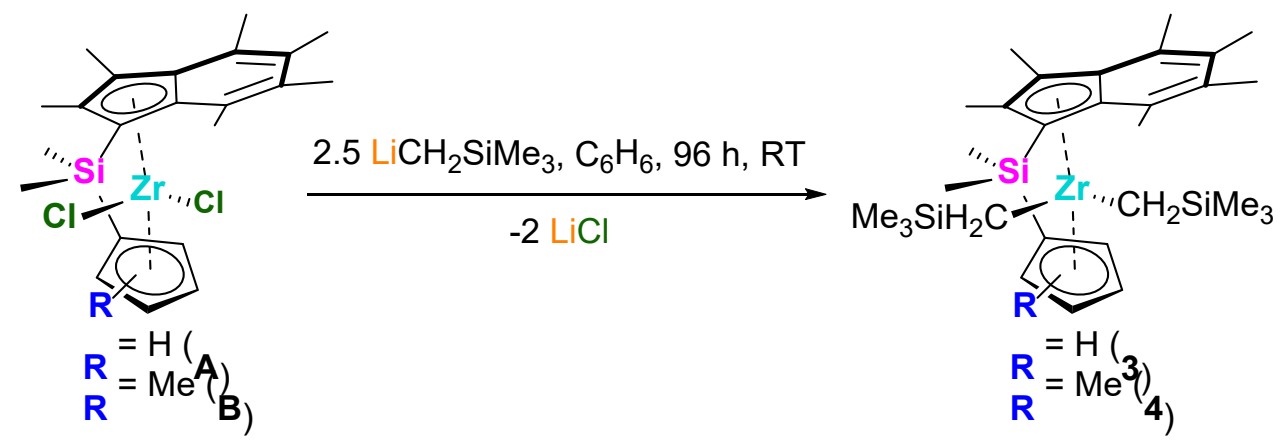

Equation 1. Synthesis of ${ }^{\mathrm{Me}_{2}} \mathrm{SB}\left(\mathrm{Cp}, \mathrm{I}^{*}\right) \mathrm{Zr}\left(\mathrm{CH}_{2} \mathrm{SiMe}_{3}\right)_{2}$ (3) and ${ }^{\mathrm{Me}_{2}} \mathrm{SB}\left(\mathrm{Cp}^{\mathrm{Me}}, \mathrm{I}^{*}\right) \mathrm{Zr}\left(\mathrm{CH}_{2} \mathrm{SiMe}_{3}\right)_{2}$ (4)

The reaction of $\mathbf{A}$ with two equivalents $\mathrm{KO}-2,6-{ }^{i} \mathrm{Pr}-\mathrm{C}_{6} \mathrm{H}_{3}$ yielded ${ }^{\mathrm{Me}_{2}} \mathrm{SB}\left(\mathrm{Cp}, \mathrm{I}^{*}\right) \mathrm{ZrCl}\left(\mathrm{O}-2,6-{ }^{i} \mathrm{Pr}-\mathrm{C}_{6} \mathrm{H}_{3}\right)$ as a mixture of the two mono-substituted isomers in a 70:30 ratio, where the aryloxide group is positioned away from and underneath the I* ligand respectively. ${ }^{\mathrm{Me}_{2}} \mathrm{SB}\left(\mathrm{Cp}, \mathrm{I}^{*}\right) \mathrm{ZrCl}\left(\mathrm{O}-2,6-{ }^{i} \mathrm{Pr}-\mathrm{C}_{6} \mathrm{H}_{3}\right)$ (5) was obtained as a single isomer from a pentane solution at $-34{ }^{\circ} \mathrm{C}$ in $14 \%$ yield, determined by ROESY NMR spectroscopy to have the aryloxide group positioned away from the I* ligand (Equation 2). In addition to the diagnostic cyclopentadienyl, permethylindenyl methyl and silyl bridge methyl resonances at 5.71-6.40, 5.15-2.46 and 0.66-0.77 ppm, 5 also shows resonances at 6.99-7.14, 3.61-3.07 and $1.30 \mathrm{ppm}$ corresponding to the aromatic, iso-propyl methyl and iso-propyl $\mathrm{CH}$ protons respectively (Figure S15).

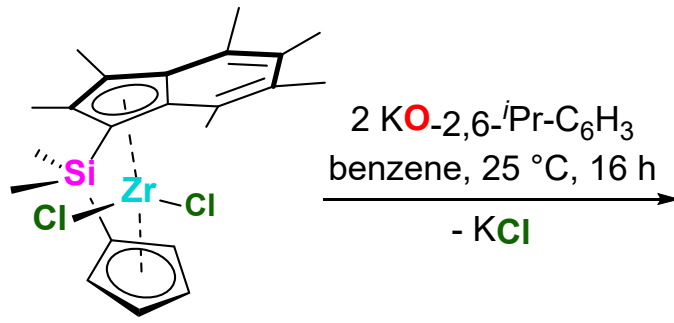

A

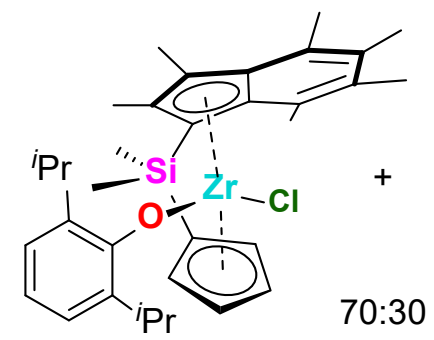

5

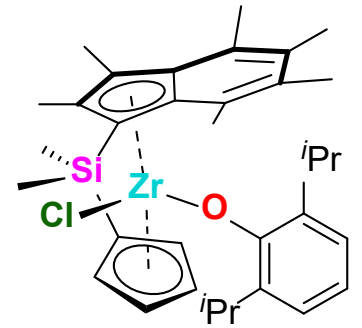

Equation 2. Synthesis of ${ }^{\mathrm{Me}_{2}} \mathrm{SB}\left(\mathrm{Cp}, \mathrm{I}^{*}\right) \mathrm{ZrCl}\left(\mathrm{O}-2,6-{ }^{i} \mathrm{Pr}^{-} \mathrm{C}_{6} \mathrm{H}_{3}\right)(\mathbf{5})$.

Yellow crystals of $\mathbf{5}$ suitable for a single crystal X-ray diffraction study were obtained from a saturated pentane solution at $-34{ }^{\circ} \mathrm{C}$. The solid-state molecular structure is depicted in Figure 2, with selected bond lengths and angles presented in Table 1. The solid-state structure confirms isolation of the isomer with the aryloxide group positioned away from the I* ligand. This is in contrast to previously reported ${ }^{\mathrm{Me}_{2}} \mathrm{SB}\left(\mathrm{Cp}, I^{*}\right) \mathrm{ZrCl}\left(\mathrm{O}-2,6-\mathrm{Me}-\mathrm{C}_{6} \mathrm{H}_{3}\right)$ where the isomer with the aryloxide group positioned below the I* ring is favoured. The change in positioning the aryloxide ligand when moving from the methyl to the iso-propyl substituted aryloxide 
moiety can be rationalised due to the sterics of the systems; the bulkier iso-propyl group is less likely to be positioned in the more sterically inaccessible position below the permethylindenyl ring.

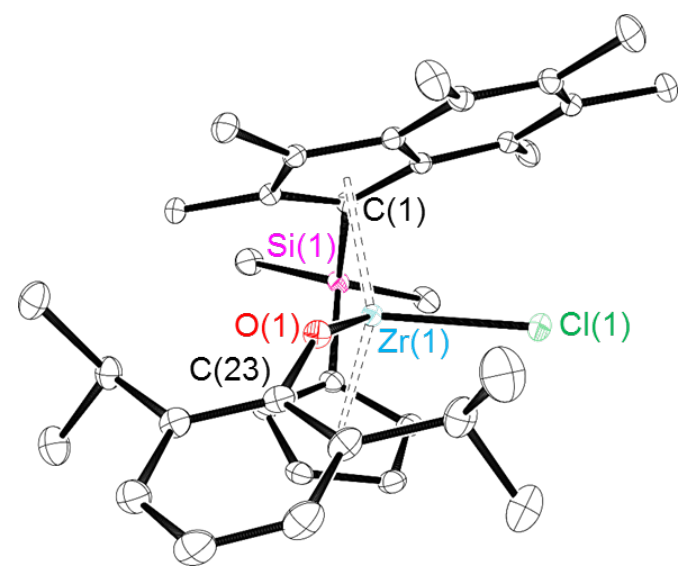

Figure 2. Solid-state molecular structure of ${ }^{\mathrm{Me}_{2}} \mathrm{SB}\left(\mathrm{Cp}, \mathrm{I}^{*}\right) \mathrm{ZrCl}\left(\mathrm{O}-2,6-{ }^{i} \mathrm{Pr}-\mathrm{C}_{6} \mathrm{H}_{3}\right)$ (5). H atoms omitted for clarity. Thermal ellipsoids drawn at 30\% probability.

Complex 5 shows $\mathrm{Zr}-\mathrm{O}$ distances comparable to the values reported for $\mathrm{Cp}_{2} \mathrm{ZrCl}(\mathrm{O}-$ 2,6- $\left.{ }^{i} \mathrm{Pr}-\mathrm{C}_{6} \mathrm{H}_{3}\right) \quad$ and $\quad{ }^{\mathrm{Me}_{2}} \mathrm{SB}\left(\mathrm{Cp}, \mathrm{I}^{*}\right) \mathrm{ZrCl}\left(\mathrm{O}-2,6-\mathrm{Me}-\mathrm{C}_{6} \mathrm{H}_{3}\right) ; \quad \mathrm{Zr}-\mathrm{O}=1.9873(11), \quad 1.97(1)$ and 1.9628(12) A respectively).[36, 39] The Zr-O bond lengths reported for $\mathbf{5}$ are significantly shorter than the sum of the covalent radii of zirconium and oxygen $(1.75$ and $0.66 \AA$ respectively), indicating that there is partial ionic character to the $\mathrm{Zr}-\mathrm{O}$ bond.[40] Complex 5 displays a smaller $\mathrm{Zr}-\mathrm{O}-\mathrm{C}$ angle than ${ }^{\mathrm{Me}_{2}} \mathrm{SB}\left(\mathrm{Cp}, \mathrm{I}^{*}\right) \mathrm{ZrCl}\left(\mathrm{O}-2,6-\mathrm{Me}_{-} \mathrm{C}_{6} \mathrm{H}_{3}\right)\left(148.31(11)^{\circ}\right.$ and $173.09(12)^{\circ}$ respectively), which suggests a lesser degree of $\pi$-orbital overlap between $\mathrm{Zr}$ and O.[36] The $\mathrm{Zr}-\mathrm{Cp}^{\mathrm{R}}$ cent and $\mathrm{Zr}$-Ind $\mathrm{Inent}_{\text {cen }}$ distances of $\mathbf{5}$ are comparable to $\mathrm{Me}_{2} \mathrm{SB}\left(\mathrm{Cp}, \mathrm{I}^{*}\right) \mathrm{ZrCl}\left(\mathrm{O}-2,6-\mathrm{Me}-\mathrm{C}_{6} \mathrm{H}_{3}\right)$ and the parent dichloride complex $\mathbf{A}\left(\mathrm{Zr}-\mathrm{Cp}^{\mathrm{R}}{ }_{\text {cent }}=\right.$ 2.2070(1), 2.2201(1) and 2.2076(1) $\AA ; Z^{2}-I n d_{c e n t}=2.2462(1), 2.2504(1)$ and 2.2244(1) $\AA$ respectively), while $\alpha$ and $\delta$ are relatively unaffected by ligand substitution from chloride to aryloxide $\left(\alpha=59.62^{\circ}\right.$ and $60.19^{\circ} ; \delta=125.29^{\circ}$ and $126.37^{\circ}$ for $\mathbf{5}$ and $\mathbf{A}$ respectively).[36]

\subsection{Polymerisation studies using sMAO}

Complexes 1-5 were immobilised onto solid polymethylaluminoxane (sMAO), according to a literature procedure, $[9]$ with an initial aluminium (in sMAO) to zirconium $\left(\left[\mathrm{Al}_{\mathrm{sMAO}}\right]_{0} /[\mathrm{Zr}]_{0}\right)$ loading of 200 (Tables S3-S7). Characterisation of three sMAO supported complexes (1 $\mathbf{1}_{\text {sMAO, }}$ 2sMAO and 3.MAO) was achieved using solid-state NMR spectroscopy (SSNMR) (Figures S17$\mathrm{S} 25)$. The ${ }^{13} \mathrm{C} C \mathrm{CP} / \mathrm{MAS}$ SSNMR spectra show a dominant resonance at approximately $-8 \mathrm{ppm}$ corresponding to the methyl groups present within the sMAO support. The spectra also show 
resonances between 15 and $40 \mathrm{ppm}$ corresponding to the methyl groups of the silyl bridge moiety and indenyl rings, in addition to the $t$-butyl groups on the fluorenyl ring for 2 sMAO (Figure S20) and the methyl groups of the neosilyl ligand for 3 sMaO (Figure S23), and resonances between 120 and $140 \mathrm{ppm}$ corresponding to the carbon atoms of the arene rings in all three complexes. The ${ }^{29} \mathrm{Si} \mathrm{CP/MAS} \mathrm{SSNMR} \mathrm{spectra} \mathrm{of} \mathbf{1}$ sMAO and $\mathbf{2}$ sMAO show a single broad resonance with maxima at -12.9 and -5.2 ppm respectively; separate environments for the two silicon atoms of the bridge cannot be identified (Figures S18 and S21). The ${ }^{29} \mathrm{Si}$ CP/MAS SSNMR spectrum of $\mathbf{3}_{\text {sMAO }}$ shows two resonances at -11.76 and $0.55 \mathrm{ppm}$ corresponding to the silicon atoms of the neosilyl ligand and bridge respectively (Figure S24). The ${ }^{27}$ Al DP/MAS SSNMR spectra for all three complexes showed a series of broad resonances between -245 and $350 \mathrm{ppm}$ due to the quadropolar aluminium nucleus $(I=5 / 2)$.

In order to determine the ideal scavenger for polymerisation, A was supported on

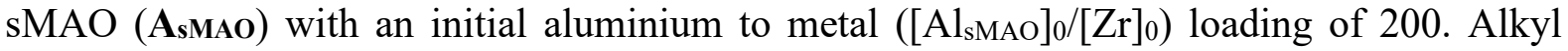
aluminium species are often added during slurry-phase polymerisation with metallocene catalysts immobilised on activated supports to scavenge impurities such as trace water and oxygen. However, they can also be used to control catalyst activity and influence polymer properties.[41-43] Slurry-phase ethylene polymerisation reactions were conducted in $150 \mathrm{~mL}$ ampoules with $50 \mathrm{~mL}$ hexane, $10 \mathrm{mg}$ pre-catalyst and 2 bar ethylene at $80{ }^{\circ} \mathrm{C}$ for 30 minutes using four different scavengers (trimethylaluminium, TMA; triethylaluminium, TEA; triisobutylaluminium, TiBA; methylaluminoxane, MAO) with an initial scavenger to zirconium $\left(\left[\mathrm{Al}_{\text {scav }}\right]_{0} /[\mathrm{Zr}]_{0}\right)$ ratio of 1000 .

It is noted that utilising MAO as the scavenger resulted in the formation of very aggregated polymer particles, likely caused by leaching of the metallocene into solution,[44] which caused stirring to cease after approximately 15 minutes. The highest polymerisation activity was recorded with TiBA, followed by TEA, MAO and TMA; activities of 5144, 4649, 3879 and $3013 \mathrm{~kg}_{\mathrm{PE}}$ molzr $^{-1} \mathrm{~h}^{-1}$ bar $^{-1}$ respectively (Figure 3 and Table S3). It is proposed that a decrease in activity on moving from TiBA to TEA scavengers may be due to formation of more stable heterobimetallic species such as $\left[\mathrm{Cp}_{2} \mathrm{M}\left(\mu-\mathrm{CH}_{2} \mathrm{R}^{\prime}\right)(\mu-\mathrm{R}) \mathrm{AlR}_{2}\right]^{+}$, where $\mathrm{R}$ is an alkyl group from the aluminium species.[45-47] It has been reported that the stability of $\mu$-alkyl complexes decrease with increasing bulk of the alkyl group, implying that the lower activity observed with TEA and TMA scavengers compared to TiBA is due to the higher stability of the heterobimetallic formed. 


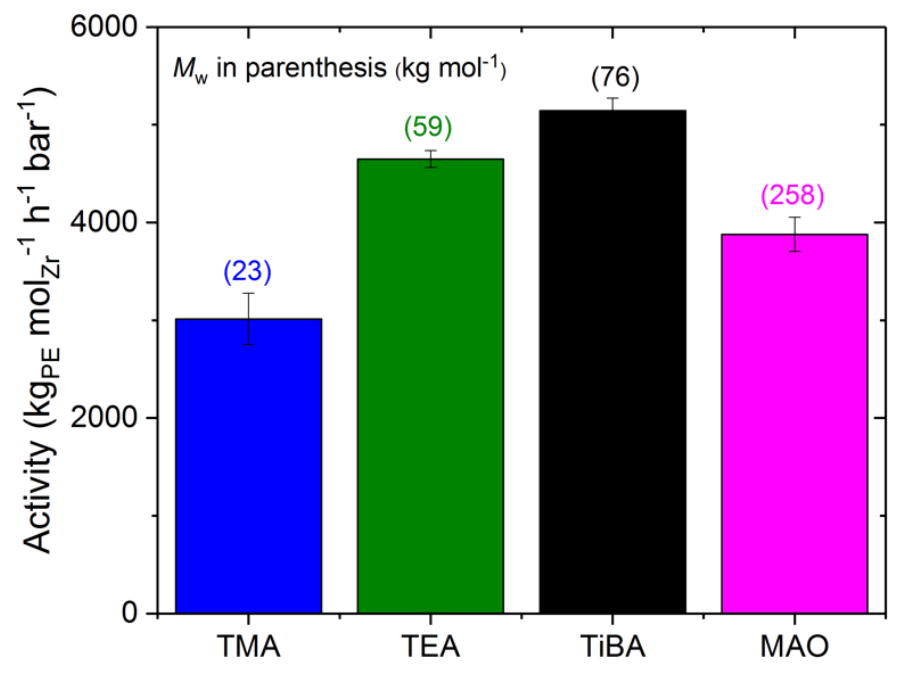

Figure 3. Slurry-phase ethylene polymerisation activity using solid MAO supported ${ }^{\mathrm{Me}_{2}} \mathrm{SB}\left(\mathrm{Cp}, \mathrm{I}^{*}\right) \mathrm{ZrCl}_{2}$ (AsMAo) with TMA (blue), TEA (green), TiBA (black) and MAO (pink) scavengers. Polymerisation conditions: $\left[\mathrm{Al}_{\mathrm{SMAO}}\right]_{0} /[\mathrm{Zr}]_{0}=200$, scavenger $\left(\left[\mathrm{Al}_{\mathrm{scav}}\right]_{0} /[\mathrm{Zr}]_{0}=\right.$ $1000)$, ethylene (2 bar), pre-catalyst $(10 \mathrm{mg})$, hexane $(50 \mathrm{~mL}), 80^{\circ} \mathrm{C}$ and 30 minutes. Molecular weights $\left(M_{\mathrm{w}}, \mathrm{kg} \mathrm{mol}^{-1}\right.$ given in parentheses).

The polyethylenes produced using Asmao with TMA, TEA, TiBA and MAO scavengers were analysed by gel permeation chromatography (GPC) (Figures 3 and 4a). The lower molecular weights $\left(M_{\mathrm{w}}\right)$ of the polymers produced using TMA and TEA compared to TiBA and MAO can be attributed to the increase in steric bulk of TiBA and MAO, which may slow the rate of chain transfer to aluminium $\left(M_{\mathrm{w}}=23,59,76\right.$ and $258 \mathrm{~kg} \mathrm{~mol}^{-1}$ ).[48, 49] Differential scanning calorimetry (DSC) analysis of the polymers revealed melting temperatures $\left(T_{\mathrm{m}}\right)$ of $132-134{ }^{\circ} \mathrm{C}$ and crystallisation temperatures $\left(T_{\mathrm{c}}\right)$ of $119-122^{\circ} \mathrm{C}$ (Figure $4 \mathrm{~b}$ and Table S10), demonstrating the production of high-density polyethylenes (HDPE) with minimal defects and branching. $[50,51]$ The enthalpy of melting $\left(\Delta \mathrm{H}_{\mathrm{m}}\right)$ and cooling $\left(\Delta \mathrm{H}_{\mathrm{c}}\right)$ were calculated from the DSC plots to be in the range $138-220 \mathrm{~J} \mathrm{~g}^{-1}$ and $143-256 \mathrm{~J} \mathrm{~g}^{-1}$ respectively. The polymers produced using TMA, TEA and TiBA as scavengers showed a higher crystallinity than those produced using MAO; 69, 87, 71 and 49\% respectively. Crystallinity is usually fairly high for HDPE as the lack of branching allows the chains to pack closely together, which leads to a higher degree of long-range order in the material.[52] The lower crystallinity of the polymers produced from MAO may be due the inhomogeneous polymer morphology observed as polymerisation proceeded. Crystallinity can also be affected by polymer molecular weights; higher molecular 
weight polymers typically have a higher degree of chain entanglement, which can lead to a lower crystallinity when relaxing from the melt. $[53,54]$

(a)

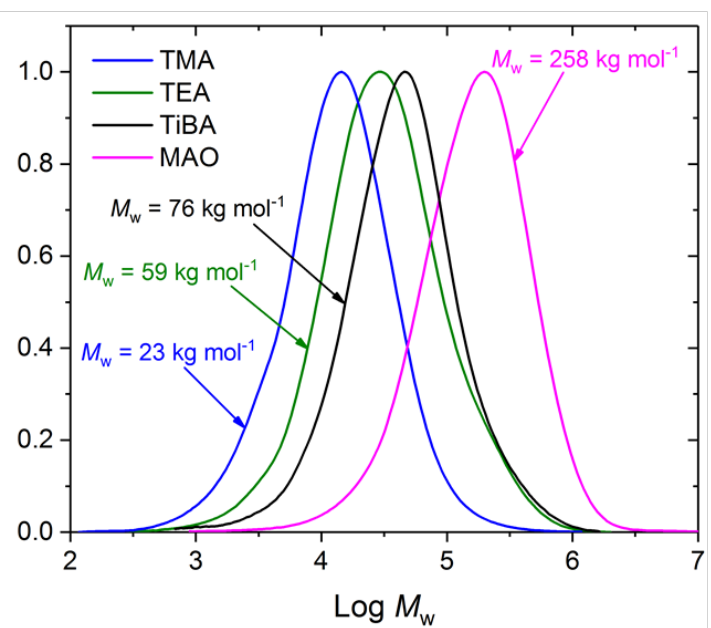

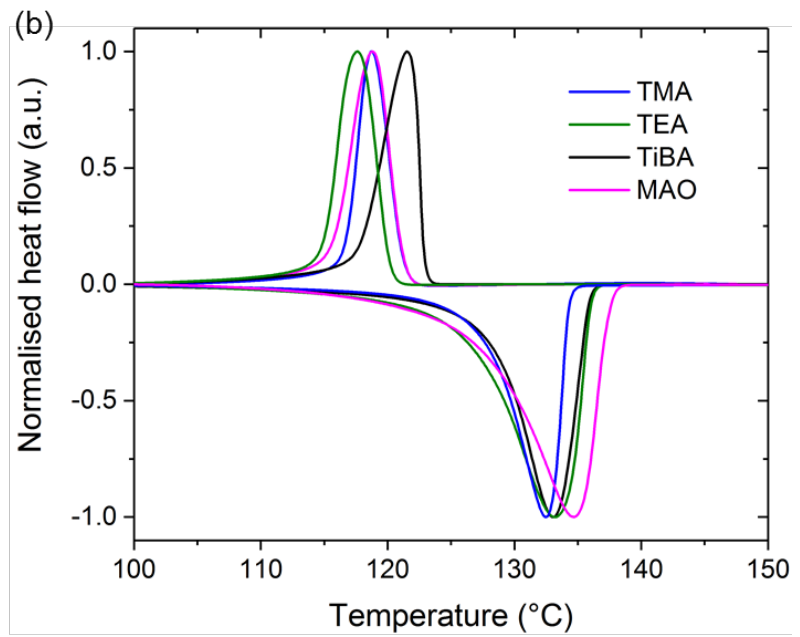

Figure 4. (a) Molecular weights distribution and (b) DSC plot showing the first cooling cycle and second heating cycle for the polyethylenes produced using sMAO supported ${ }^{\mathrm{Me}_{2}} \mathrm{SB}\left(\mathrm{Cp}, \mathrm{I}^{*}\right) \mathrm{ZrCl}_{2}$ (AsMAo) with TMA (blue), TEA (green), TiBA (black) and MAO (pink) scavenger. Normalised for clarity. Polymerisation conditions: $\left[\mathrm{Al}_{\mathrm{SMAO}}\right]_{0} /[\mathrm{Zr}]_{0}=200$, scavenger $\left([\mathrm{Alscav}]_{0} /[\mathrm{Zr}]_{0}=1000\right)$, ethylene $(2 \mathrm{bar})$, pre-catalyst $(10 \mathrm{mg})$, hexane $(50 \mathrm{~mL}), 80{ }^{\circ} \mathrm{C}$ and 30 minutes.

Following on from this study, the slurry-phase polymerisation of ethylene using 1-5 supported on SMAO was investigated. Polymerisations were conducted in $150 \mathrm{~mL}$ ampoules with $150 \mathrm{mg}$ TiBA $\left(\left[\mathrm{Al}_{\text {scav }}\right]_{0} /[\mathrm{Zr}]_{0}=1000\right), 50 \mathrm{~mL}$ hexane, $10 \mathrm{mg}$ pre-catalyst and 2 bar ethylene for 30 minutes between 50 and $90{ }^{\circ} \mathrm{C}$. Figure 5 shows that $\mathbf{1}_{\text {sMaO, }}$ 2sMAO and 5sMaO display significantly lower slurry-phase ethylene polymerisation activities than 3sMAO and 4sMAO; 573, 355, 549, 4301 and $3564 \mathrm{~kg}_{\mathrm{PE}}$ molzr $^{-1} \mathrm{~h}^{-1} \mathrm{bar}^{-1}$ respectively at $80{ }^{\circ} \mathrm{C}$. The disilyl bridged species $\mathbf{1}_{\text {sMAO }}$ and $\mathbf{2}_{\mathbf{s M A O}}$ also display much lower polymerisation activities than the monosilyl bridges analogues (activities of 5144 and $\quad 6013 \mathrm{~kg}_{\mathrm{PE}} \mathrm{mol}_{\mathrm{Zr}}{ }^{-1} \mathrm{~h}^{-1} \mathrm{bar}^{-1}$ for $\mathrm{sMAO}-{ }^{\mathrm{Me}_{2}} \mathrm{SB}\left(\mathrm{Cp}, \mathrm{I}^{*}\right) \mathrm{ZrCl}_{2}$ and sMAO- ${ }^{\mathrm{Me}_{2}} \mathrm{SB}\left({ }^{t \mathrm{Bu}_{2}} \mathrm{Flu}, \mathrm{I}^{*}\right) \mathrm{ZrCl}_{2}$ respectively at $\left.80{ }^{\circ} \mathrm{C}\right) \cdot[7,35]$ The decreased activity is likely due to the increased flexibility of the disilyl bridge.[6] For $\mathbf{2}_{\mathbf{s M A O}}$, the lower polymerisation activity may also be a consequence of the decreased size of the coordination site when compared to ${ }^{\mathrm{Me}_{2}} \mathrm{SB}\left({ }^{t \mathrm{Bu}_{2}} \mathrm{Flu}, \mathrm{I}^{*}\right) \mathrm{ZrCl}_{2}\left(\delta=139.7^{\circ}\right.$ and $131.0^{\circ}$ respectively),[7] which may reduce the accessibility of the metal centre to ethylene monomers. 


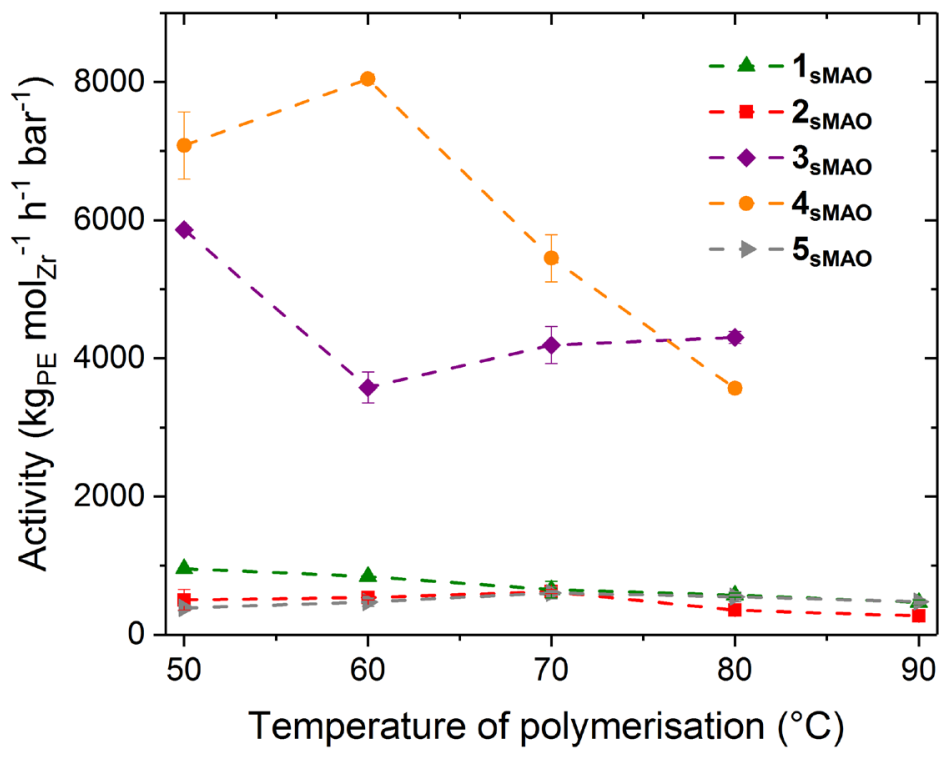

Figure 5. Slurry-phase ethylene polymerisation activity as a function of temperature of polymerisation using sMAO supported ${ }^{\mathrm{Me}_{4}} \mathrm{DSB}\left(\mathrm{Cp}, \mathrm{I}^{*}\right) \mathrm{ZrCl}_{2} \quad$ (1 $\mathbf{1}_{\text {sMAO}}$; green triangle),


diamond), $\quad \mathrm{Me}_{2} \mathrm{SB}\left(\mathrm{Cp}^{\mathrm{Me}}, \mathrm{I}^{*}\right) \mathrm{Zr}\left(\mathrm{CH}_{2} \mathrm{SiMe}_{3}\right)_{2} \quad$ (4, sMAO; orange circle) and $\mathrm{Me}_{2} \mathrm{SB}\left(\mathrm{Cp}, \mathrm{I}^{*}\right) \mathrm{ZrCl}\left(\mathrm{O}-2,6-{ }^{i} \mathrm{Pr}-\mathrm{C}_{6} \mathrm{H}_{3}\right)\left(\mathbf{5}_{\text {sMaO }}\right.$; grey right triangle). Polymerisation conditions: $\left[\mathrm{Al}_{\mathrm{sMAO}}\right]_{0} /[\mathrm{Zr}]_{0}=200, \mathrm{TiBA}(150 \mathrm{mg})$, ethylene $(2 \mathrm{bar})$, pre-catalyst $(10 \mathrm{mg})$, hexane $(50 \mathrm{~mL})$ and 30 minutes.

The addition of an aryloxide group significantly reduces the polymerisation activity of 5sMAO compared to parent dichloride complex AsMAO (activities of 549 and $5144 \mathrm{~kg}_{\mathrm{PE}} \mathrm{mol}_{\mathrm{Zr}}{ }^{-}$ ${ }^{1} \mathrm{~h}^{-1}$ bar $^{-1}$ respectively at $80{ }^{\circ} \mathrm{C}$ ). This is opposite to the effect seen by Firth et al., where the solution-phase polymerisation of ethylene with $\mathrm{Cp}_{2} \mathrm{ZrCl}\left(\mathrm{O}-2,{ }^{-}{ }^{i} \mathrm{Pr}-\mathrm{C}_{6} \mathrm{H}_{3}\right)$ showed an $11 \%$ increase in activity compared to the parent dichloride complex $\mathrm{Cp}_{2} \mathrm{ZrCl}_{2}$ (1 bar ethylene at room temperature).[39] Conversely, Repo et al. reported that the solution-phase polymerisation of ethylene with $\mathrm{Cp}_{2} \mathrm{ZrCl}\left(\mathrm{O}-2,6-{ }^{i} \mathrm{Pr}_{-} \mathrm{C}_{6} \mathrm{H}_{3}\right)$ with 2 bar ethylene at $30{ }^{\circ} \mathrm{C}$ gave a slightly lower polymerisation activity than $\mathrm{Cp}_{2} \mathrm{ZrCl}_{2}$ (995 and $1100 \mathrm{~kg}_{\mathrm{PE}}$ molzr ${ }^{-1} \mathrm{~h}^{-1} \mathrm{bar}^{-1}$ respectively).[55] In order to further understand the mechanism of polymerisation, Firth et al. demonstrated that the reaction of $\mathrm{Cp}_{2} \mathrm{ZrCl}\left(\mathrm{O}-2,6-{ }^{i} \mathrm{Pr}-\mathrm{C}_{6} \mathrm{H}_{3}\right)$ with two equivalents of TMA resulted in the formation of $\mathrm{Cp}_{2} \mathrm{ZrMe}_{2}$ (via $\mathrm{Cp}_{2} \mathrm{ZrMe}\left(\mathrm{O}-2,6-{ }^{i} \mathrm{Pr}-\mathrm{C}_{6} \mathrm{H}_{3}\right.$ )) and aluminium by-product $\left[\mathrm{AlMe}_{2}\left(\mathrm{O}-2,6-{ }^{i} \mathrm{Pr}-\mathrm{C}_{6} \mathrm{H}_{3}\right)\right]_{\mathrm{n}}$,[39] highlighting that polymerisation activity is at least partially dependent on the efficiency of X ligand abstraction by the co-catalyst. It is postulated that the leaving group becomes bound to the solid support during immobilisation.[56] Therefore, the 
bulky aryloxide group could influence polymerisation activity by altering the second order sphere of coordination of the catalyst,[57] potentially weakening the interaction between the inner-sphere ion pair (composed of the cationic catalyst and anionic counterion)[57] and reducing the barriers to insertion.[58, 59]

3.MAO shows a fairly constant activity across the temperature range (between 5862 and $4302 \mathrm{~kg}_{\mathrm{PE}}$ mol $_{\mathrm{Zr}}^{-1} \mathrm{~h}^{-1} \mathrm{bar}^{-1}$ ), but a lower polymerisation activity than the dichloride analogue Asmao (activities of 5862 and $6794 \mathrm{~kg}_{\mathrm{PE}}$ molzr $^{-1} \mathrm{~h}^{-1}$ bar $^{-1}$ at $50{ }^{\circ} \mathrm{C}$ respectively). In contrast, $4_{\text {sMAO }}$ shows a sharp decrease in polymerisation activity above $60{ }^{\circ} \mathrm{C}$, indicating a lack of thermal stability, and a higher polymerisation activity than the dichloride analogue $\mathbf{B}_{\text {sMaO }}$ before decomposition (activities of 8042 and $4223 \mathrm{~kg}_{\mathrm{PE}} \mathrm{molzr}^{-1} \mathrm{~h}^{-1} \mathrm{bar}^{-1}$ respectively at $60{ }^{\circ} \mathrm{C}$ ).


${ }^{\mathrm{Me}_{2}} \mathrm{SB}\left(\mathrm{Cp}, \mathrm{I}^{*}\right) \mathrm{Zr}\left(\mathrm{CH}_{2} \mathrm{Ph}\right)_{2}$ across the temperature range while $\mathbf{4}_{\text {sMAO }}$ shows a higher activity than ${ }^{\mathrm{Me}_{2}} \mathrm{SB}\left(\mathrm{Cp}^{\mathrm{Me}}, \mathrm{I}^{*}\right) \mathrm{Zr}\left(\mathrm{CH}_{2} \mathrm{Ph}\right)_{2}$ below $70{ }^{\circ} \mathrm{C}$ (activities of 6265 and $6729 \mathrm{~kg}_{\mathrm{PE}}$ mol $_{\mathrm{Zr}^{-1}} \mathrm{~h}^{-1}$ bar $^{-}$ ${ }^{1}$ respectively at $\left.60{ }^{\circ} \mathrm{C}\right) \cdot[35]$

1sMaO, 2sMaO and 5sMaO show significantly lower ethylene polymerisation activities across the temperature range than industrial standard sMAO- $\left(\mathrm{Cp}^{n \mathrm{Bu}}\right)_{2} \mathrm{ZrCl}_{2}$ under the same conditions $\left(573,355,549\right.$ and $3459 \mathrm{~kg}_{\mathrm{PE}}$ mol $_{\mathrm{Zr}}^{-1} \mathrm{~h}^{-1} \mathrm{bar}^{-1}$ respectively at $\left.80{ }^{\circ} \mathrm{C}\right) .3_{\text {sMAO }}$ shows a higher activity than sMAO- $\left(\mathrm{Cp}^{n \mathrm{Bu}}\right)_{2} \mathrm{ZrCl}_{2}$ at all temperatures except $60{ }^{\circ} \mathrm{C}(5862$ and $4367 \mathrm{~kg}_{\mathrm{PE}}$ mol $_{\mathrm{Zr}}^{-1} \mathrm{~h}^{-1} \mathrm{bar}^{-1}$ respectively at $50^{\circ} \mathrm{C}$ ), while $\mathbf{4}_{\text {sMaO }}$ shows a higher activity than sMAO- $\left(\mathrm{Cp}^{n \mathrm{Bu}}\right)_{2} \mathrm{ZrCl}_{2}$ below $70{ }^{\circ} \mathrm{C}\left(8042\right.$ and $4641 \mathrm{~kg}_{\mathrm{PE}} \mathrm{mol}_{\mathrm{Zr}^{-1}} \mathrm{~h}^{-1} \mathrm{bar}^{-1}$ respectively at $\left.60{ }^{\circ} \mathrm{C}\right)$.

The polyethylenes produced using $\mathbf{1}_{\text {sMAO }}$, 2 sMAO, 3 sMAO and $\mathbf{5}_{\text {sMAO }}$ were analysed by GPC (Figure 6). $M_{\mathrm{w}}$ was observed to decrease with increasing polymerisation temperature, attributed to faster chain transfer reactions at higher temperatures,[60] and an increase in the rate of termination relative to propagation; at elevated temperatures, the system has more energy to overcome the higher activation barrier of termination.[61] $\mathbf{2}_{\text {sMAO }}$ produced polymers with the highest molecular weights, followed by $\mathbf{1}_{\text {sMAO, }} \mathbf{3}_{\text {sMAO }}$ and $\mathbf{5}_{\text {sMAO }} ; M_{\mathrm{w}}=567,289,196$ and $160 \mathrm{~kg} \mathrm{~mol}^{-1}$ at $80{ }^{\circ} \mathrm{C}$. This implies that the longer the silyl bridging moiety, the higher the molecular weight of the resulting polyethylenes. 1sMaO and 2 2 sAO produced polymers with molecular weights approximately 3.5 and 1.3 times larger than the corresponding one atom silyl bridged species sMAO- ${ }^{\mathrm{Me}_{2}} \mathrm{SB}\left(\mathrm{Cp}, \mathrm{I}^{*}\right) \mathrm{ZrCl}_{2}$ and sMAO- ${ }^{\mathrm{Me}_{2}} \mathrm{SB}\left({ }^{t \mathrm{Bu}_{2}} \mathrm{Flu} \mathrm{I}^{*}\right) \mathrm{ZrCl}_{2}$.[7, 35] The polymers also displayed wide molecular weight distributions $\left(M_{\mathrm{w}} / M_{\mathrm{n}}=6.7-8.1\right.$ and 8.4-17.9 for $\mathbf{1}_{\text {sMAO }}$ and $\mathbf{2}_{\text {SMAO }}$ respectively) implying that a variety of surface sites may exist. $\mathbf{3}_{\text {SMAO }}$ and $\mathbf{5}_{\text {sMAO }}$ produced polymers with molecular weights lower than $\mathbf{1}_{\text {sMAO }}$ and $\mathbf{2}_{\text {sMAO}}$; however, $M_{\mathrm{W}}$ 
were approximately 2.5 times larger than the polyethylenes produced using parent complex Asmao $\left(76 \mathrm{~kg} \mathrm{~mol}^{-1}\right.$ at $80{ }^{\circ} \mathrm{C}$ ).[35] Similarly to $\mathbf{A}_{\mathbf{s M a O}}$, the polymers produced using $\mathbf{3}_{\mathbf{s M a O}}$ and 5sMAO displayed low molecular weight distributions $\left(M_{\mathrm{w}} / M_{\mathrm{n}}=3.0-4.3\right.$ and $2.8-3.1$ respectively), indicating that the species behave largely as single-site catalysts.
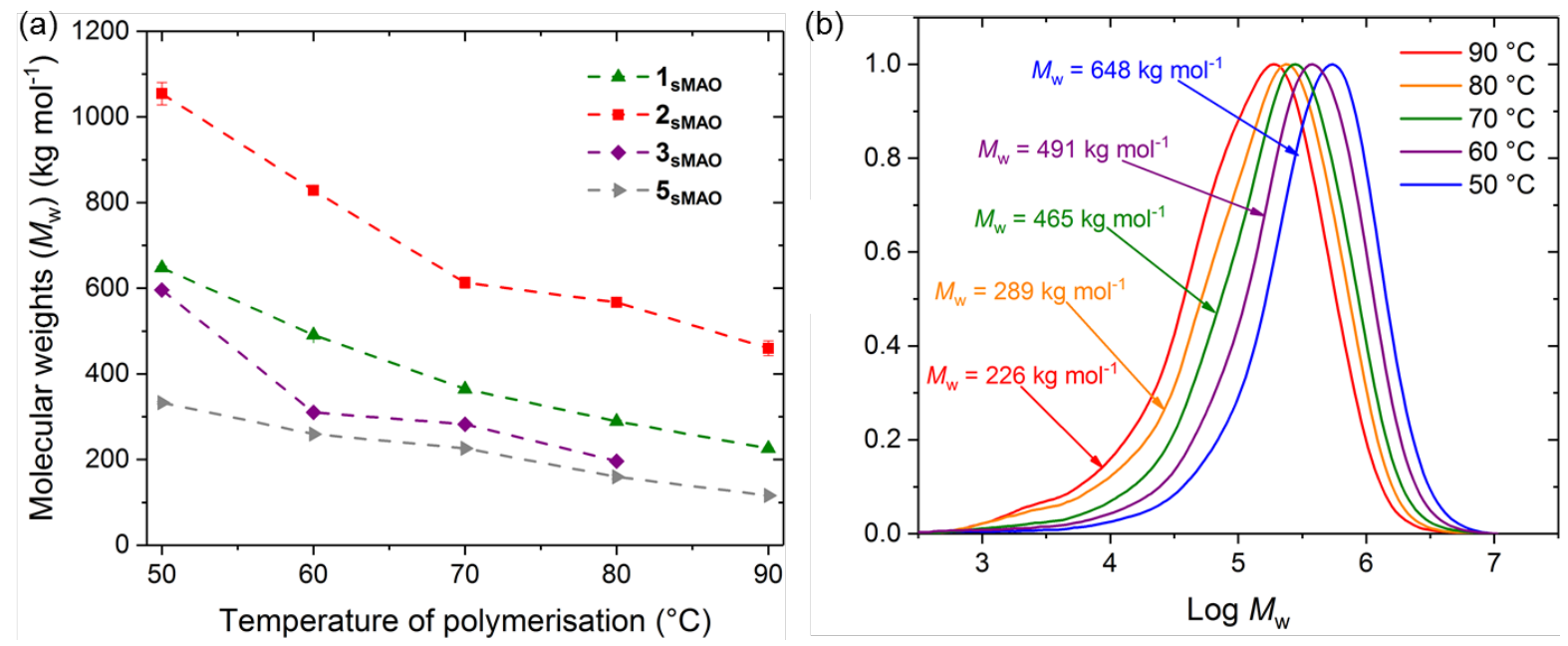

Figure 6 (a) Molecular weights $\left(M_{\mathrm{w}}\right)$ as a function of temperature of polymerisation using

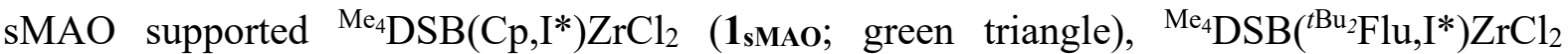
(2 $\mathbf{2}_{\text {sMAO; }}$ red square), ${ }^{\mathrm{Me}_{2}} \mathrm{SB}\left(\mathrm{Cp}, \mathrm{I}^{*}\right) \mathrm{Zr}\left(\mathrm{CH}_{2} \mathrm{SiMe}_{3}\right)_{2} \quad\left(\mathbf{3}_{\mathbf{s M A O}} ; \quad\right.$ purple diamond) and ${ }^{\mathrm{Me}_{2}} \mathrm{SB}\left(\mathrm{Cp}, \mathrm{I}^{*}\right) \mathrm{ZrCl}\left(\mathrm{O}-2,6-{ }^{i} \mathrm{Pr}_{-} \mathrm{C}_{6} \mathrm{H}_{3}\right) \quad\left(\mathbf{5}_{\text {sMAO; }}\right.$; grey right triangle); (b) Molecular weights distribution for sMAO supported ${ }^{\mathrm{Me}_{4}} \mathrm{DSB}\left(\mathrm{Cp}, \mathrm{I}^{*}\right) \mathrm{ZrCl}_{2}\left(\mathbf{1}_{\text {sMAo }}\right.$ ) at $50{ }^{\circ} \mathrm{C}$ (blue), $60{ }^{\circ} \mathrm{C}$ (purple), $70{ }^{\circ} \mathrm{C}$ (green), $80^{\circ} \mathrm{C}$ (orange) and $90{ }^{\circ} \mathrm{C}$ (red). Normalised for clarity. Polymerisation conditions: $\left[\mathrm{Al} l_{\mathrm{SMAO}}\right]_{0} /[\mathrm{Zr}]_{0}=200$, TiBA $(150 \mathrm{mg})$, ethylene $(2 \mathrm{bar})$, pre-catalyst $(10 \mathrm{mg})$, hexane $(50 \mathrm{~mL})$ and 30 minutes.

Scanning electron microscopy (SEM) analysis of the polyethylenes produced using 1 sMAO, 2 sMAO, 3 sMAO, 4 sMAO and $5_{\text {sMAO }}$ showed the formation of industrially desirable, uniform 'popcorn' morphology with good flowability,[7] mimicking the morphology of the solid support (via the templating effect) (Figure 7a-e).[25] 1sMAO, 2

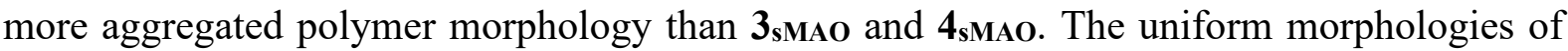
the polyethylenes produced using the supported systems are in contrast to the poor morphology produced by homogeneous polymerisation using 2 , which can lead to reactor fouling and limits the large scale industrial applications of this system (Figure 7f). 


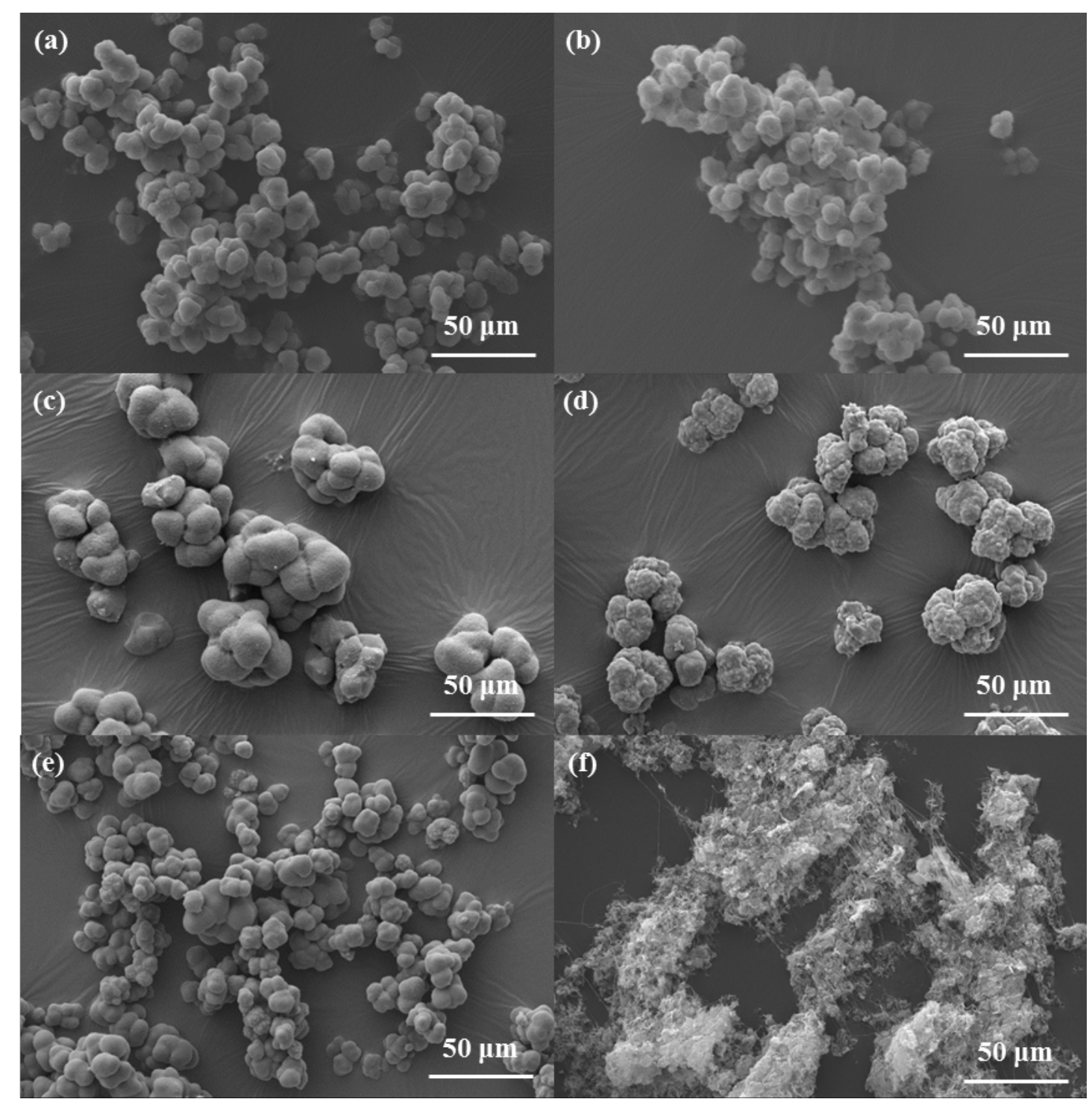

Figure 7. SEM images at $\times 500$ magnification of the polymers produced from the slurry-phase

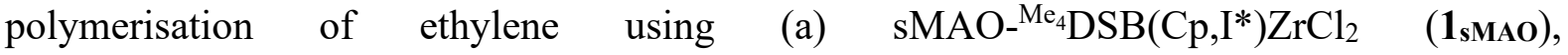
(b) $\mathrm{sMAO}-{ }^{\mathrm{Me}_{4}} \mathrm{DSB}\left({ }^{t \mathrm{Bu}_{2}} \mathrm{Flu}, \mathrm{I}^{*}\right) \mathrm{ZrCl}_{2}$ (2 $\left.\mathbf{2}_{\mathbf{s M A O}}\right)$, (c) sMAO- ${ }^{\mathrm{Me}_{2}} \mathrm{SB}\left(\mathrm{Cp}, \mathrm{I}^{*}\right) \mathrm{Zr}\left(\mathrm{CH}_{2} \mathrm{SiMe}_{3}\right)_{2}\left(\mathbf{3}_{\mathbf{s M A O}}\right)$, (d) $\mathrm{sMAO}-{ }^{\mathrm{Me}_{2}} \mathrm{SB}\left(\mathrm{Cp}^{\mathrm{Me}}, \mathrm{I}^{*}\right) \mathrm{Zr}\left(\mathrm{CH}_{2} \mathrm{SiMe}_{3}\right)_{2} \quad$ (4, $\left.\mathbf{\text { sMo }}\right), \quad$ (e) ${ }^{\mathrm{Me}_{2}} \mathrm{SB}\left(\mathrm{Cp}, \mathrm{I}^{*}\right) \mathrm{ZrCl}\left(\mathrm{O}-2,6-{ }^{i} \mathrm{Pr}-\mathrm{C}_{6} \mathrm{H}_{3}\right)\left(\mathbf{5}_{\mathbf{s M A O}}\right)$ and (f) ${ }^{\mathrm{Me}_{4}}{ } \mathrm{DSB}\left({ }^{\left(\mathrm{Bu}_{2}\right.} \mathrm{Flu} \mathrm{I}^{*}\right) \mathrm{ZrCl}_{2}$ (2).

Powder X-ray diffraction (PXRD) analysis of the polymers produced using 1sMao, 2sMaO, 3 3 sao and $\mathbf{4}_{\text {sMaO }}$ in slurry-phase polymerisation showed sharp reflections at approximately $21.5^{\circ}$ and $24.0^{\circ}$ (corresponding to the (110) and (200) planes respectively), which is characteristic of crystalline HDPE (Figure 8). 


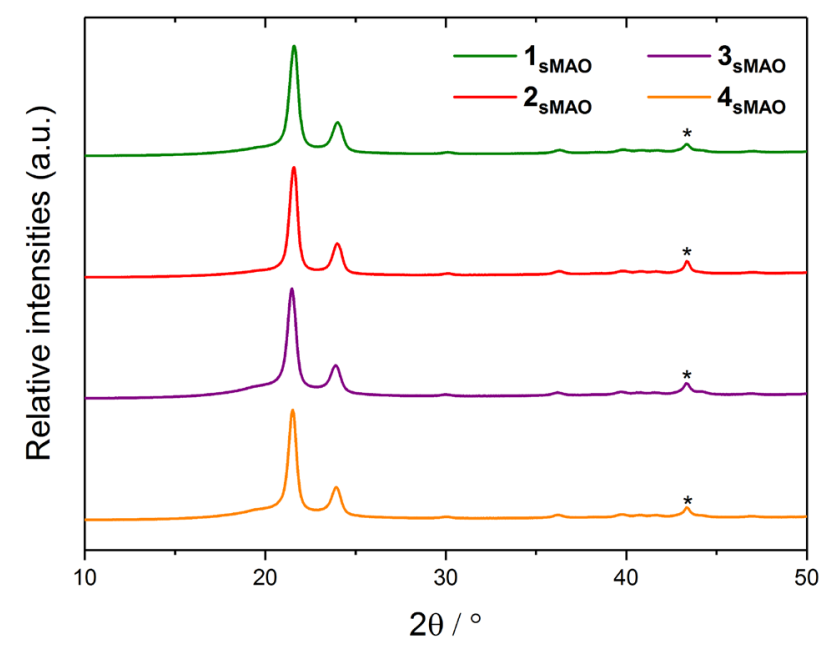

Figure 8. PXRD pattern for the polyethylenes produced using sMAO supported

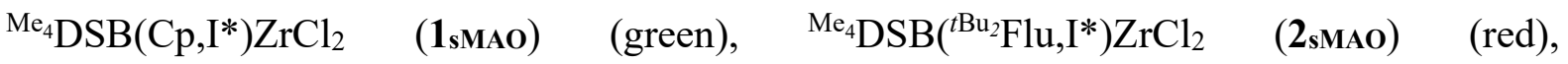

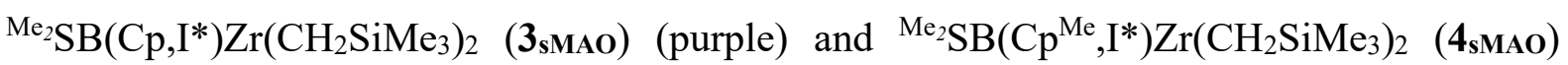
(orange). *Denotes the reflection for the sample holder. Polymerisation conditions: $\left[\mathrm{Al}_{\mathrm{sMAO}}\right]_{0} /[\mathrm{Zr}]_{0}=200, \mathrm{TiBA}(150 \mathrm{mg})$, ethylene $(2 \mathrm{bar})$, pre-catalyst $(10 \mathrm{mg})$, hexane $(50 \mathrm{~mL})$, $80{ }^{\circ} \mathrm{C}$ and 30 minutes.

DSC analysis of the polyethylenes produced by $\mathbf{1}_{\text {sMaO, }} \mathbf{2}_{\text {sMaO }}, \mathbf{3}_{\text {sMaO }}, \mathbf{4}_{\text {sMaO }}$ and $\mathbf{5}_{\text {sMaO }}$ in slurry-phase polymerisation revealed $T_{\mathrm{m}}$ of $134-137^{\circ} \mathrm{C}$ and $T_{\mathrm{c}}$ of $113-119{ }^{\circ} \mathrm{C}$ (Figure 9 and Table S11), further confirming the production of HDPE and showing the presence of minimal defects and branching.[50, 51] For the polyethylenes produced by $\mathbf{1}_{\text {sMAO, }} \mathbf{2}_{\text {sMAO, }} \mathbf{3}_{\text {sMAO }}, \mathbf{4}_{\text {sMAO }}$ and $\mathbf{5}_{\text {sMAO, }} \Delta \mathrm{H}_{\mathrm{m}}$ and $\Delta \mathrm{H}_{\mathrm{c}}$ were calculated from the DSC plots in the range 126-167 $\mathrm{J} \mathrm{g}^{-1}$ and $132-166 \mathrm{~J} \mathrm{~g}^{-1}$ respectively with $45-57 \%$ polymer crystallinity (Table S10). 3sMAO and $\mathbf{5}_{\text {sMAO }}$ displayed lower $T_{\mathrm{c}}$ and higher $T_{\mathrm{m}}$ than parent complex AsMao; $T_{\mathrm{c}}$ of 114,117 and $122{ }^{\circ} \mathrm{C}$ respectively and $T_{\mathrm{m}}$ of 137,135 and $133{ }^{\circ} \mathrm{C}$ respectively.[35] A higher $T_{\mathrm{m}}$ usually indicates a higher density polymer with fewer branches.[62] The crystallinities of the polymers produced using 3 3 Mao and 5sMao were significantly lower than for the polymer produced using AsMaO $(45,57$ and $75 \%$ respectively). This is expected based on the higher molecular weights of the polymers produced from 3sMaO and 5sMao compared to AsMao,[35] which can lead to more chain entanglements and hinder crystal formation and growth $\left(M_{\mathrm{w}}=196,160\right.$ and $76 \mathrm{~kg} \mathrm{~mol}^{-1}$ respectively at $\left.80^{\circ} \mathrm{C}\right) \cdot[53,54]$ 


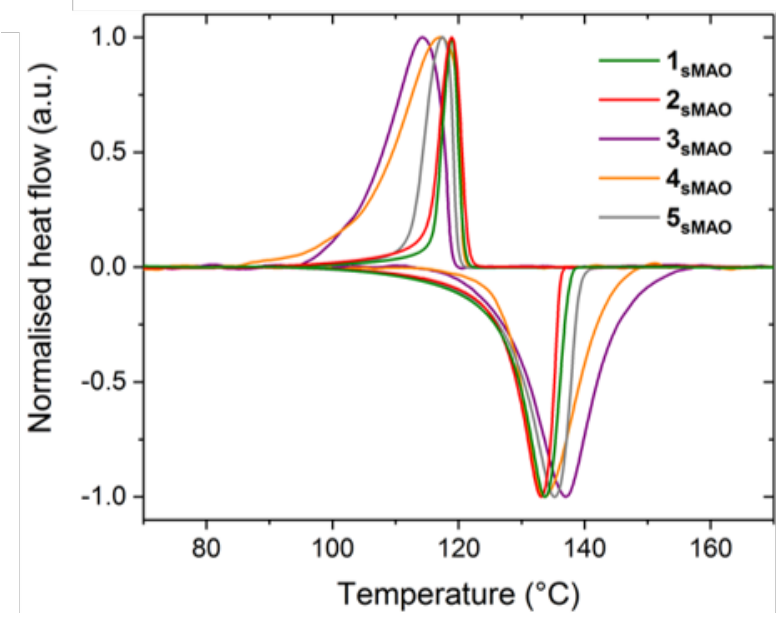

Figure 9. DSC plot showing the first cooling cycle and second heating cycle for the polyethylenes produced using sMAO supported ${ }^{\mathrm{Me}_{4}} \mathrm{DSB}\left(\mathrm{Cp}, \mathrm{I}^{*}\right) \mathrm{ZrCl}_{2}$ (1 $\mathbf{1}_{\text {sMAO}}$ ) (green),

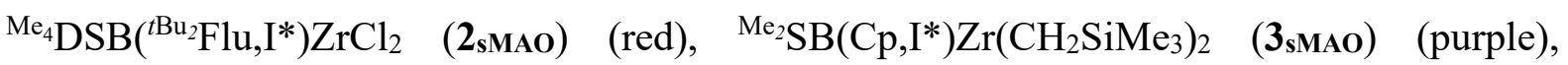
${ }_{\mathrm{Me}_{2}} \mathrm{SB}\left(\mathrm{Cp}^{\mathrm{Me}}, \mathrm{I}^{*}\right) \mathrm{Zr}\left(\mathrm{CH}_{2} \mathrm{SiMe}_{3}\right)_{2} \quad$ (4 sMAo (orange) and ${ }^{\mathrm{Me}_{2}} \mathrm{SB}\left(\mathrm{Cp}, \mathrm{I}^{*}\right) \mathrm{ZrCl}\left(\mathrm{O}-2,6-{ }^{i} \mathrm{Pr}-\mathrm{C}_{6} \mathrm{H}_{3}\right)$ (5 $\mathbf{5}_{\text {sMAO }}$ (grey). Normalised for clarity. Polymerisation conditions: $\left[\mathrm{Al}_{\mathrm{sMAO}}\right]_{0} /[\mathrm{Zr}]_{0}=200$, TiBA $(150 \mathrm{mg})$, ethylene (2 bar), pre-catalyst $(10 \mathrm{mg})$, hexane $(50 \mathrm{~mL}), 80^{\circ} \mathrm{C}$ and 30 minutes.

\subsection{Polymerisation studies using LDHMAO}

Recently, the use of MAO-activated thermally treated aqueous miscible organic solvent treated layered double hydroxides (LDHMAO) as well-defined supports for the immobilisation of single-site $\alpha$-olefin polymerisation catalysts has emerged.[35, 63, 64] Aqueous miscible organic solvent treated layered double hydroxides (AMO-LDHs) are the product of an aqueous miscible organic solvent treatment (AMOST) method, where the AMO solvent is typically acetone or ethanol. The resulting crystalline AMO-LDHs display uniform particle sizes smaller than $0.5 \mu \mathrm{m}$ and possess surface areas and pore volumes significantly higher than conventional and commercial LDHs.[65, 66] AMO-LDH supports are industrially desirable as they are simple to synthesise on a large scale, more cost-effective than silica and show no evidence of reactor fouling or catalyst leaching.[65]

Complex 3 was immobilised onto LDHMAO $\left(\mathrm{Mg}_{2} \mathrm{Al}-\mathrm{CO}_{3}\right)$ (3 $\mathbf{3}_{\text {LDHMAO) }}$ with $\left[\mathrm{Al}_{\mathrm{sMAO}}\right]_{0} /[\mathrm{Zr}]_{0}=200$ following an analogous procedure to sMAO. Characterisation of 3LDHMAO was achieved using SSNMR spectroscopy (Figures S26-S28). Similarly to $\mathbf{3}_{\text {sMAO, the }}$ ${ }^{13} \mathrm{C}$ CP/MAS SSNMR spectrum of 3LDHMAO shows a dominant resonance at approximately -8 ppm corresponding to the methyl groups present within MAO, weak resonances between 15 and $75 \mathrm{ppm}$ corresponding to the methyl groups of the silyl bridge, indenyl rings and neosilyl 
ligand, and weak resonances between 120 and $140 \mathrm{ppm}$ corresponding to the carbon atoms of the arene rings. In addition, the spectrum also shows a dominant resonance at $167 \mathrm{ppm}$ corresponding to the carbonate within LDHMAO support (Figure S26). The ${ }^{29} \mathrm{Si}$ CP/MAS SSNMR spectrum shows two resonances at -13.6 and $0.8 \mathrm{ppm}$ corresponding to the silicon atoms of the neosilyl ligand and bridge respectively (Figure S27), while the ${ }^{27} \mathrm{Al}$ DP/MAS SSNMR spectrum shows a series of broad resonances between -245 and $450 \mathrm{ppm}$ (Figure S28).

3LDHMAO displayed a peak polymerisation activity of $4747 \mathrm{~kg}_{\mathrm{PE}} \mathrm{mol}_{\mathrm{Zr}}{ }^{-1} \mathrm{~h}^{-1} \mathrm{bar}^{-1}$ respectively at $70{ }^{\circ} \mathrm{C}$; similar to that of $\mathbf{3}_{\text {sMAO }}\left(4191 \mathrm{~kg}_{\mathrm{PE}} \mathrm{mol}_{\mathrm{Zr}^{-1}} \mathrm{~h}^{-1} \mathrm{bar}^{-1}\right.$ ) (Figure 10 and Table S9). 3LdHмao displayed much higher slurry-phase ethylene polymerisation activities than Aldhmao and LDHMAO supported ( $\left.{ }^{2-\mathrm{Me}, 4-\mathrm{Ph}} \mathrm{SBI}\right) \mathrm{ZrCl}_{2}\left(4253,68\right.$ and $3226 \mathrm{~kg}_{\mathrm{PE}} \mathrm{mol}_{\mathrm{Zr}}{ }^{-}$ ${ }^{1} \mathrm{~h}^{-1}$ bar $^{-1}$ respectively at $\left.60{ }^{\circ} \mathrm{C}\right)$. [35, 64] 3LDHмao also displayed slurry-phase ethylene polymerisation activities approximately double that of industrial standard $\left(\mathrm{Cp}^{n \mathrm{Bu}}\right)_{2} \mathrm{ZrCl}_{2}$ supported on LDHMAO (4253 and $2141 \mathrm{~kg}_{\mathrm{PE}} \mathrm{mol}_{\mathrm{Zr}}^{-1} \mathrm{~h}^{-1} \mathrm{bar}^{-1}$ at $60{ }^{\circ} \mathrm{C}$ ).[64]

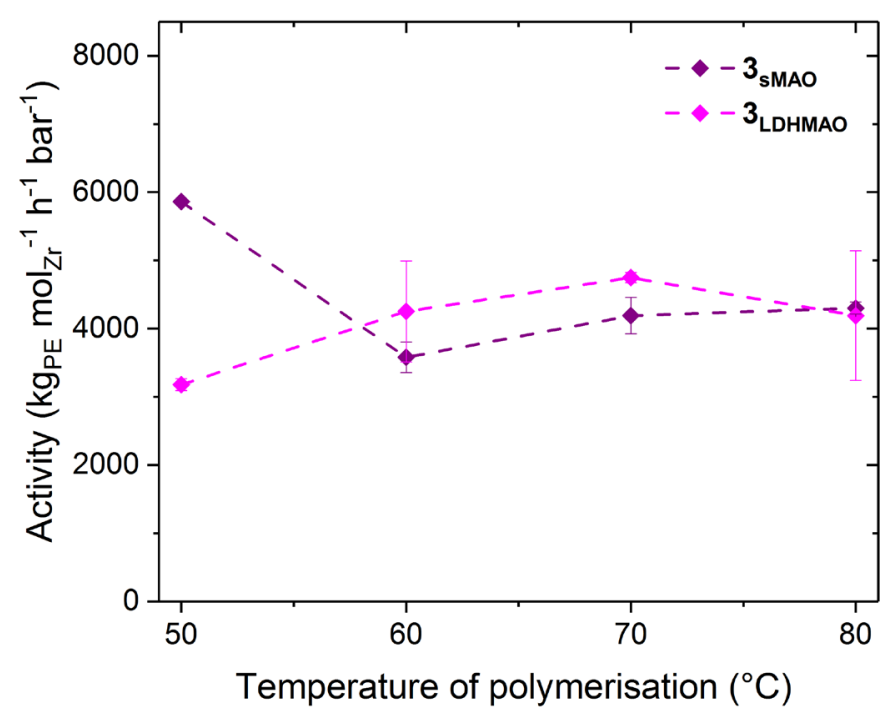

Figure 10. Slurry-phase ethylene polymerisation activity as a function of temperature of polymerisation using sMAO- ${ }^{{ }^{-}}{ }_{2} \mathrm{SB}\left(\mathrm{Cp}, \mathrm{I}^{*}\right) \mathrm{Zr}\left(\mathrm{CH}_{2} \mathrm{SiMe}_{3}\right)_{2} \quad\left(\mathbf{3}_{\text {sMaO }}\right) \quad$ (purple) and LDHMAO- ${ }^{\mathrm{Me}_{2}} \mathrm{SB}\left(\mathrm{Cp}, \mathrm{I}^{*}\right) \mathrm{Zr}\left(\mathrm{CH}_{2} \mathrm{SiMe}_{3}\right)_{2}$ (3 (3DHMAo) (pink). Polymerisation conditions: $\left[\mathrm{Al}_{\text {support }}\right]_{0} /[\mathrm{Zr}]_{0}=200, \mathrm{TiBA}(150 \mathrm{mg})$, ethylene $(2 \mathrm{bar})$, pre-catalyst $(10 \mathrm{mg})$, hexane $(50 \mathrm{~mL})$ and 30 minutes.

SEM analysis of the polyethylenes produced using 3LDHMAO showed the formation of aggregated, non-uniform polymer particles, mimicking the morphology of the solid support 
(Figure 11). The same effect was also observed for ${ }^{\mathrm{Me}_{2}} \mathrm{SB}\left(\mathrm{Cp}^{\mathrm{R}}, \mathrm{I}^{*}\right) \mathrm{ZrCl}_{2}(\mathrm{R}=\mathrm{H}$ and Me) and ${ }^{\mathrm{Me}_{2}} \mathrm{SB}\left({ }^{t \mathrm{Bu}} \mathrm{Flu}, \mathrm{I}^{*}\right) \mathrm{ZrCl}_{2}$ supported on sMAO and LDHMAO.[7, 35] The flowability of the polymer produced using $\mathbf{3}_{\text {LDHMAO }}$ was reduced when compared to $\mathbf{3}_{\text {sMAO, }}$, likely due to the more aggregated morphology of the LDHMAO support leading to a poorer templating effect.[35]

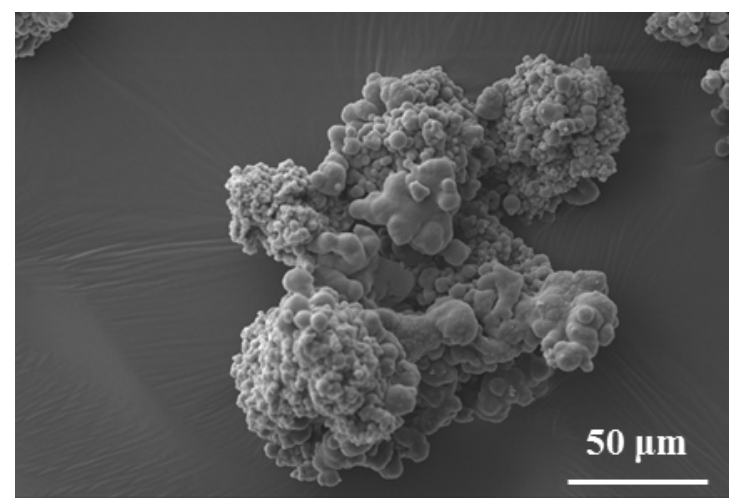

Figure 11. SEM image at $\times 500$ magnification of the polymers produced from the slurry-phase polymerisation of ethylene using LDHMAO- ${ }^{\mathrm{Me}_{2}} \mathrm{SB}\left(\mathrm{Cp}, \mathrm{I}^{*}\right) \mathrm{Zr}\left(\mathrm{CH}_{2} \mathrm{SiMe}_{3}\right)_{2}$ (3 $\left.\mathbf{L D H M A O}\right)$.

DSC analysis of the polyethylenes produced by $\mathbf{3}_{\text {LDHMAo revealed }} T_{\mathrm{m}}$ and $T_{\mathrm{c}}$ identical to the polyethylenes produced using $3_{\text {sMAO }}$ (137 and $114{ }^{\circ} \mathrm{C}$ respectively) (Figure 12); confirming the production of HDPE with minimal defects and branching. $[50,51]$ The enthalpy of melting $\left(\Delta \mathrm{H}_{\mathrm{m}}\right)$ and cooling $\left(\Delta \mathrm{H}_{\mathrm{c}}\right)$ were calculated as $105 \mathrm{~J} \mathrm{~g}^{-1}$ and $128 \mathrm{~J} \mathrm{~g}^{-1}$ respectively with polymer crystallinity similar to the polyethylenes produced using $\mathbf{3}_{\text {sMAO }}$ ( 44 and $45 \%$ ) respectively.




Figure 12. DSC plot showing the first cooling cycle and second heating cycle for the polyethylenes produced using sMAO- ${ }_{2} \mathrm{SB}\left(\mathrm{Cp}, \mathrm{I}^{*}\right) \mathrm{Zr}\left(\mathrm{CH}_{2} \mathrm{SiMe}_{3}\right)_{2}$ (3.

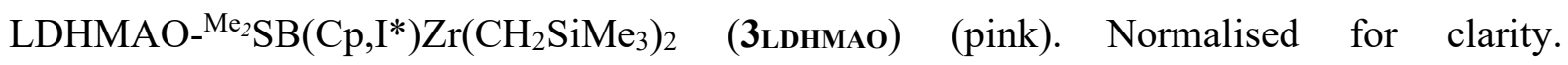
Polymerisation conditions: $\left[\mathrm{A} 1_{\text {support }}\right]_{0} /[\mathrm{Zr}]_{0}=200$, TiBA $(150 \mathrm{mg})$, ethylene (2 bar), pre-catalyst $(10 \mathrm{mg})$, hexane $(50 \mathrm{~mL}), 80^{\circ} \mathrm{C}, 30$ minutes.

\section{Conclusions}

Five new permethylindenyl zirconocene complexes have been synthesised and fully

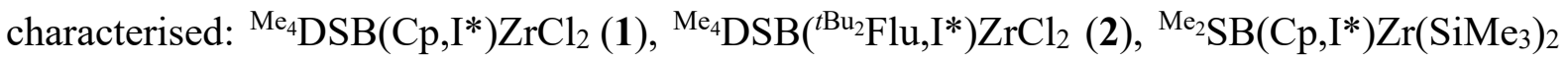
(3), ${ }^{\mathrm{Me}_{2}} \mathrm{SB}\left(\mathrm{Cp}^{\mathrm{Me}}, \mathrm{I}^{*}\right) \mathrm{Zr}\left(\mathrm{SiMe}_{3}\right)_{2}$ (4) and ${ }^{\mathrm{Me}_{2}} \mathrm{SB}\left(\mathrm{Cp}, \mathrm{I}^{*}\right) \mathrm{ZrCl}\left(\mathrm{O}-2,6-{ }^{i} \mathrm{Pr}_{-} \mathrm{C}_{6} \mathrm{H}_{3}\right)$ (5). The complexes were immobilised on solid polymethylaluminoxane (sMAO) and the slurry-phase ethylene polymerisation activity studied at various temperatures.

4sMAO displayed the highest ethylene polymerisation activity $\left(8042 \mathrm{~kg}_{\mathrm{PE}} \mathrm{mol}_{\mathrm{Zr}}^{-1} \mathrm{~h}^{-1}\right.$ $\operatorname{bar}^{-1}$ at $\left.60{ }^{\circ} \mathrm{C}\right) ; 73 \%$ more active than an industrial standard, sMAO- $\left(\mathrm{Cp}^{n \mathrm{Bu}}\right)_{2} \mathrm{ZrCl}_{2}$, under the same conditions. The polyethylenes produced using 1sMaO, 2 $\mathbf{s M a O}$, 3sMao and 5sMaO showed relatively low molecular weights $M_{\mathrm{W}}<650 \mathrm{~kg} \mathrm{~mol}^{-1}$ at $80{ }^{\circ} \mathrm{C}$. $\mathbf{1}_{\text {sMAO }}$ and $\mathbf{2}_{\text {sMAO }}$ produced polymers with wide molecular weight distributions $\left(M_{\mathrm{w}} / M_{\mathrm{n}}=6.7-8.1\right.$ and $8.4-17.9$ respectively) implying that a variety of surface sites may exist, while $\mathbf{3}_{\text {sMAO }}$ and $\mathbf{5}_{\text {sMaO }}$ produced polymers low molecular weight distributions $\left(M_{\mathrm{w}} / M_{\mathrm{n}}=3.0-4.3\right.$ and $2.8-3.1$ respectively) indicating that the species behave largely as single-site catalysts. SEM analysis of the polyethylenes showed the formation of industrially desirable, uniform, 'popcorn' morphology in all cases.

$\mathrm{Me}_{2} \mathrm{SB}\left(\mathrm{Cp}, \mathrm{I}^{*}\right) \mathrm{Zr}\left(\mathrm{SiMe}_{3}\right)_{2}$ (3) was also immobilised on MAO modified layered double hydroxide (LDHMAO). Polymerisation activity was similar to the same complex immobilised on sMAO, however polymer morphology was much more aggregated and less uniform.

\section{Experimental}

\subsection{Synthesis of Ind $*\left(\mathrm{SiMe}_{2}\right)_{2} \mathrm{Cl}$}

1.0 equivalent $\mathrm{Ind}^{\#} \mathrm{H}(10.0 \mathrm{~g}, 50.0 \mathrm{mmol})$ was dissolved in pentane $(100 \mathrm{~mL})$. The solution was cooled to $0{ }^{\circ} \mathrm{C}$ and 1.1 equivalents ${ }^{n} \mathrm{BuLi}(22.0 \mathrm{~mL}, 2.5 \mathrm{M}$ in hexanes, $55.0 \mathrm{mmol})$ added dropwise. The reaction was allowed to warm to room temperature, stirred for $18 \mathrm{~h}$ and the solvent removed in vacuo. The resulting lithium salt was dissolved in THF (100 mL) and added dropwise to a solution of 3.0 equivalents $\left(\mathrm{Me}_{2} \mathrm{SiCl}\right)_{2}(27.9 \mathrm{~mL}, 150.3 \mathrm{mmol})$. The reaction was stirred for $2 \mathrm{~h}$, the solvent removed and the product extracted with pentane $(2 \times 30 \mathrm{~mL})$. 
Storage at $-34{ }^{\circ} \mathrm{C}$ yielded Ind* $\left(\mathrm{SiMe}_{2}\right)_{2} \mathrm{Cl}$ as a pale yellow solid in $70 \%$ yield $(12.3 \mathrm{~g}$, $35.0 \mathrm{mmol}) .{ }^{1} \mathrm{H}$ NMR $\left(\mathrm{C}_{4} \mathrm{D}_{8} \mathrm{O}, 400 \mathrm{MHz}, 298 \mathrm{~K}\right) \delta(\mathrm{ppm}): 3.56(\mathrm{SiCH}, 1 \mathrm{H}, \mathrm{s}), 2.49(\mathrm{C}=\mathrm{CMe}$, 3H, s), 2.24 (ArMe, 3H, s), 2.22 (ArMe, 3H, s), 2.21 (ArMe, 3H, s), 2.20 (ArMe, 3H, s), 2.10 (C=CMe, 3H, s), 0.36 (SiMe, 3H, s), 0.24 (SiMe, 3H, s), 0.20 (SiMe, 3H, s) and -0.21 (SiMe, $3 \mathrm{H}, \mathrm{s}) .{ }^{13} \mathrm{C}\left\{{ }^{1} \mathrm{H}\right\} \mathrm{NMR}\left(\mathrm{C}_{4} \mathrm{D}_{8} \mathrm{O}, 125 \mathrm{MHz}, 298 \mathrm{~K}\right) \delta$ (ppm): 143.1 (Ar), 141.7 (Ar), 141.0 (Ar), 133.2 (Ar), 133.0 (Ar), 130.9 (Ar), 127.7 (Ar), 127.2 (Ar), 47.9 (ArSi), 19.3 (ArMe), 16.5 (ArMe), 16.4 (ArMe), 15.8 (ArMe), 15.7 (ArMe), 3.2 (SiMe), 2.4 (SiMe), -1.2 (SiMe) and -1.6 (SiMe).

\subsection{Synthesis of ${ }^{\mathrm{Me}_{4}} \mathrm{DSB}\left(\mathrm{Cp}, I^{*}\right) \mathrm{Li}_{2}$}

1.0 equivalent $\mathrm{LiCp}(0.205 \mathrm{~g}, 2.85 \mathrm{mmol})$ and 1.0 equivalent $\mathrm{Ind}^{*}\left(\mathrm{SiMe}_{2}\right)_{2} \mathrm{Cl}(1.00 \mathrm{~g}$, $2.85 \mathrm{mmol})$ were dissolved in THF $(20 \mathrm{~mL})$ and stirred for $2 \mathrm{~h}$ at room temperature. 2.2 equivalents ${ }^{n} \mathrm{BuLi}(3.9 \mathrm{~mL}, 1.6 \mathrm{M}$ in hexane, $6.27 \mathrm{mmol})$ were added drop-wise at $0{ }^{\circ} \mathrm{C}$, after which the reaction mixture was allowed to warm to room temperature and stirred for 1 hour. The solvent was removed in vacuo and the residue washed with pentane $(3 \times 20 \mathrm{~mL})$ and diethyl ether $(3 \times 30 \mathrm{~mL})$. The resulting solid was dried to afford ${ }^{{ }^{\mathrm{Me}}}{ }_{4} \mathrm{DSB}\left(\mathrm{Cp}, \mathrm{I}^{*}\right) \mathrm{Li}_{2}$ as a brown powder in $78 \%$ yield $(0.880 \mathrm{~g}, 2.24 \mathrm{mmol}) .{ }^{1} \mathrm{H}$ NMR $\left(\mathrm{C}_{5} \mathrm{D}_{5} \mathrm{~N}, 400 \mathrm{MHz}, 298 \mathrm{~K}\right) \delta(\mathrm{ppm})$ : 6.56 (CpH, 2H, m), 6.27 (CpH, 2H, m), 3.06 (ArMe, 3H, s), 2.84 (ArMe, 3H, s), 2.75 (ArMe, 3H, s), 2.73 (ArMe, 3H, s), 2.43 (ArMe, 3H, s), 2.39 (ArMe, 3H, s), 0.92 (SiMe, $6 \mathrm{H}, \mathrm{s})$ and 0.83 (SiMe, 6H, s). ${ }^{13} \mathrm{C}\left\{{ }^{1} \mathrm{H}\right\} \mathrm{NMR}\left(\mathrm{C}_{5} \mathrm{D}_{5} \mathrm{~N}, 125 \mathrm{MHz}, 298 \mathrm{~K}\right) \delta(\mathrm{ppm}): 136.0$ (Ar), 135.0 (Ar), 134.2 (Ar), 131.0 (Ar), 122.3 (Ar), 120.3 (Ar), 120.8 (Ar), 112.7 (Ar), 111.6 (Cp), 107.7 (Cp), 105.7 (CpSi), 89.6 (ArSi), 24.0 (ArMe), 18.5 (ArMe), 17.9 (ArMe), 17.8 (ArMe), 17.2 (ArMe), 16.1 (ArMe), 6.4 (SiMe) and 0.7 (SiMe).

\subsection{Synthesis of ${ }^{M e_{4}} \mathrm{DSB}\left({ }^{\mathrm{Bu} u_{2}} \mathrm{Flu}, \mathrm{I}^{*}\right) \mathrm{Li}_{2} .\left(\mathrm{Et}_{2} \mathrm{O}\right)_{1.5}$}

1.0 equivalent ${ }^{t \mathrm{Bu}_{2}} \mathrm{FluLi}(1.13 \mathrm{~g}, 2.85 \mathrm{mmol})$ and 1.0 equivalent $\mathrm{Ind} *\left(\mathrm{SiMe}_{2}\right)_{2} \mathrm{Cl}(1.00 \mathrm{~g}$, $2.85 \mathrm{mmol})$ were dissolved in THF $(30 \mathrm{~mL})$ and stirred for $2 \mathrm{~h}$ at room temperature. 2.2 equivalents ${ }^{n} \mathrm{BuLi}\left(3.9 \mathrm{~mL}, 1.6 \mathrm{M}\right.$ in hexane, $6.27 \mathrm{mmol}$ ) were added drop-wise at $0{ }^{\circ} \mathrm{C}$, after which the reaction mixture was allowed to warm to room temperature and stirred for 1 hour. The solvent was removed in vacuo and the residue washed with pentane $(3 \times 50 \mathrm{~mL})$ and diethyl ether $(2 \times 50 \mathrm{~mL})$. The solid was dried to afford $\left.{ }^{\mathrm{Me}_{4}} \mathrm{DSB}^{t \mathrm{Bu}_{2}} \mathrm{Flu}, \mathrm{I}^{*}\right) \mathrm{Li}_{2} .\left(\mathrm{Et}_{2} \mathrm{O}\right)_{1.5}$ as a yellow solid in $19 \%$ yield $(0.381 \mathrm{~g}, 0.532 \mathrm{mmol}) .{ }^{1} \mathrm{H}$ NMR $\left(\mathrm{C}_{5} \mathrm{D}_{5} \mathrm{~N}, 400 \mathrm{MHz}, 298 \mathrm{~K}\right) \delta$ (ppm): $8.50\left(\right.$ FluH, 2H, d, $\left.{ }^{3} J_{\mathrm{H}-\mathrm{H}}=4 \mathrm{~Hz}\right), 8.47(\mathrm{FluH}, 2 \mathrm{H}, \mathrm{s}), 7.12\left(\mathrm{FluH}, 2 \mathrm{H}, \mathrm{dd},{ }^{3} J_{\mathrm{H}-\mathrm{H}}=\right.$ $8.0 \mathrm{~Hz}), 3.36\left(\mathrm{OCH}_{2} \mathrm{CH}_{3}, 4 \mathrm{H}, \mathrm{q},{ }^{3} J_{\mathrm{H}-\mathrm{H}}=8 \mathrm{~Hz}\right), 3.02$ (ArMe, 3H, s), 2.88 (ArMe, 3H, s), 
2.76 (ArMe, 3H, s), 2.75 (ArMe, 3H, s), 2.35 (ArMe, 3H, s), 2.23 (ArMe, 3H, s), 1.64 $\left(\right.$ Flu $\left.{ }^{t} \mathbf{B u}, 18 \mathrm{H}, \mathrm{s}\right), 1.28(\mathrm{SiMe}, 6 \mathrm{H}, \mathrm{s}), 1.14\left(\mathrm{OCH}_{2} \mathbf{C H}_{3}, 6 \mathrm{H}, \mathrm{t},{ }^{3} \mathrm{~J}_{\mathrm{H}-\mathrm{H}}=8 \mathrm{~Hz}\right)$ and 1.07 (SiMe, $6 \mathrm{H}, \mathrm{s}) .{ }^{13} \mathrm{C}\left\{{ }^{1} \mathrm{H}\right\}$ NMR $\left(\mathrm{C}_{5} \mathrm{D}_{5} \mathrm{~N}, 125 \mathrm{MHz}, 298 \mathrm{~K}\right) \delta(\mathrm{ppm}): 149.8$ (Ar), 146.2 (Ar), 141.4 (Ar), 136.5 (Ar), 135.1 (Ar), 126.0 (Ar), 124.5 (Ar), 124.4 (Ar), 124.1 (Ar), 123.9 (Ar), 123.4 (Ar), 119.1 (FluH), 116.1 (FluH), 108.7 (FluH), 105.2 (ArSi), $66.3\left(\mathrm{OCH}_{2} \mathrm{CH}_{3}\right), 35.7$ (FluSi), 33.4 (Flut ${ }^{t} \mathbf{B u}$ ), 26.3 (ArMe), 23.6 (ArMe), 18.3 (ArMe), 17.5 (ArMe), 17.0 (ArMe), 16.2 (ArMe), $16.0\left(\mathrm{OCH}_{2} \mathbf{C H}\right), 7.0(\mathrm{SiMe})$ and $3.4(\mathrm{SiMe})$.

\subsection{Synthesis of ${ }^{M e_{4}} \mathrm{DSB}\left(\mathrm{Cp}, I^{*}\right) \mathrm{ZrCl}_{2}$ (1)}

1.0 equivalent ${ }^{\mathrm{Me}_{4}} \mathrm{DSB}\left(\mathrm{Cp}, \mathrm{I}^{*}\right) \mathrm{Li}_{2}(0.880 \mathrm{~g}, 2.24 \mathrm{mmol})$ and 1.0 equivalent $\mathrm{ZrCl}_{4}(0.520 \mathrm{~g}$, $2.24 \mathrm{mmol})$ were dissolved in benzene $(30 \mathrm{~mL})$ and stirred at room temperature for $18 \mathrm{~h}$. The resulting orange solution was filtered, the solvent removed and the product extracted with pentane $(3 \times 20 \mathrm{~mL})$. The insoluble orange solid was shown by ${ }^{1} \mathrm{H}$ NMR spectroscopy to be the desired product in $7 \%$ yield $(0.086 \mathrm{~g}, 0.159 \mathrm{mmol})$. Storage of the pentane solution at $-34{ }^{\circ} \mathrm{C}$ yielded another crop of ${ }^{\mathrm{Me}_{4}} \mathrm{DSB}\left(\mathrm{Cp}, \mathrm{I}^{*}\right) \mathrm{ZrCl}_{2}$ (1) as an orange solid in $13 \%$ yield (0.122 g, $226 \mathrm{mmol}) .{ }^{1} \mathrm{H}$ NMR $\left(\mathrm{C}_{6} \mathrm{D}_{6}, 400 \mathrm{MHz}, 298 \mathrm{~K}\right) \delta(\mathrm{ppm}): 6.84(\mathrm{CpH}, 1 \mathrm{H}, \mathrm{m}), 6.41$ (CpH, 1H, m), 5.74 (CpH, 1H, m), 5.67 (CpH, 1H, m), 2.63 (ArMe, 3H, s), 2.62 (ArMe, 3H, s), 2.60 (ArMe, 3H, s), 2.30 (ArMe, 3H, s), 2.01 (ArMe, 3H, s), 1.98 (ArMe, 3H, s), 0.60 (SiMe, 3H, s), 0.46 (SiMe, 3H, s), 0.37 (SiMe, 3H, s) and 0.35 (SiMe, 3H, s). ${ }^{13} \mathrm{C}\left\{{ }^{1} \mathrm{H}\right\}$ NMR $\left(\mathrm{C}_{6} \mathrm{D}_{6}\right.$, $125 \mathrm{MHz}, 298 \mathrm{~K}$ ) $\delta$ (ppm): 147.7 (Ar), 133.4 (Ar), 132.5 (Ar), 132.3 (Ar), 131.9 (Ar), 131.0 (Ar), 130.9 (Ar), 129.9 (Ar), 123.0 (Cp), 120.4 (Cp), 119.8 (Cp), 119.4 (Cp), 115.9 (CpSi), 102.6 (ArSi), 23.6 (ArMe), 18.0 (ArMe), 17.3 (ArMe), 17.0 (ArMe), 16.7 (ArMe), 15.0 (ArMe), 5.0 (SiMe), 3.6 (SiMe), -1.0 (SiMe) and -2.3 (SiMe). ${ }^{29} \mathrm{Si} \mathrm{NMR}\left(\mathrm{C}_{6} \mathrm{D}_{6}, 100 \mathrm{MHz}\right.$, $298 \mathrm{~K}) \delta$ (ppm): -17.0 (SiMe) and -21.7 (SiMe). CHN Analysis (\%): expected C 53.41, H 6.46, observed C 53.47, H 6.50. CCDC number: 1958152.

\subsection{Synthesis of ${ }^{\mathrm{Me}_{4}} \mathrm{DSB}\left({ }^{\mathrm{B} u_{2}} \mathrm{Flu}, \mathrm{I}^{*}\right) \mathrm{ZrCl}_{2}(2)$}

1.0 equivalent ${ }^{{ }^{\mathrm{Me}}{ }_{4}} \mathrm{DSB}\left({ }^{t \mathrm{Bu}_{2}} \mathrm{Flu}_{\mathrm{I}} \mathrm{I}^{*}\right) \mathrm{Li}_{2} .\left(\mathrm{Et}_{2} \mathrm{O}\right)_{1.5}(0.380 \mathrm{~g}, 0.530 \mathrm{mmol})$ and 1.0 equivalent $\mathrm{ZrCl}_{4}$ $(0.120 \mathrm{~g}, 0.530 \mathrm{mmol})$ were dissolved in benzene $(30 \mathrm{~mL})$ and stirred for $18 \mathrm{~h}$ at room temperature. The resulting orange solution was filtered, the solvent removed and the product extracted with pentane $(3 \times 20 \mathrm{~mL})$. The insoluble orange powder was shown by ${ }^{1} \mathrm{H}$ NMR spectroscopy to be the desired product in $22 \%$ yield $(0.086 \mathrm{~g}, 0.114 \mathrm{mmol})$. Storage of the filtrate at $-80{ }^{\circ} \mathrm{C}$ yielded another crop of ${ }^{\mathrm{Me}_{4}} \mathrm{DSB}\left({ }^{\left(\mathrm{Bu}_{2}\right.} \mathrm{Flu}, \mathrm{I}^{*}\right) \mathrm{ZrCl}_{2}(2)$ as orange crystals suitable for a single crystal X-ray diffraction study in $52 \%$ yield $(0.122 \mathrm{~g}, 0.162 \mathrm{mmol}) .{ }^{1} \mathrm{H}$ NMR $\left(\mathrm{C}_{6} \mathrm{D}_{6}\right.$, 
$400 \mathrm{MHz}, 298 \mathrm{~K}) \delta(\mathrm{ppm}): 7.86\left(\right.$ FluH, $\left.1 \mathrm{H}, \mathrm{d},{ }^{3} J_{\mathrm{H}-\mathrm{H}}=8 \mathrm{~Hz}\right), 7.70\left(\right.$ FluH, $\left.1 \mathrm{H}, \mathrm{d},{ }^{3} J_{\mathrm{H}-\mathrm{H}}=8 \mathrm{~Hz}\right)$, 7.69 (FluH, 1H, s) 7.62 (FluH, 1H, s), 7.59 (FluH, 1H, dd, $\left.{ }^{3} J_{\mathrm{H}-\mathrm{H}}=8 \mathrm{~Hz}\right), 7.40$ (FluH, 1H, dd, ${ }^{3} J_{\mathrm{H}-\mathrm{H}}=8 \mathrm{~Hz}$ ), 2.84 (ArMe, 3H, s), 2.35 (ArMe, 3H, s), 2.32 (ArMe, 3H, s), 2.06 (ArMe, 3H, s), 2.03 (ArMe, 3H, s), 2.02 (ArMe, 3H, s), 1.40 (Flu $\left.{ }^{t} \mathbf{B u}, 9 H, s\right), 1.32$ (Flu ${ }^{t} \mathbf{B u}, 9 H$, s), 0.86 (SiMe, 3H, s), 0.86 (SiMe, 3H, s), 0.71 (SiMe, 3H, s) and 0.67 (SiMe, 3H, s). ${ }^{13} \mathrm{C}\left\{{ }^{1} \mathrm{H}\right\}$ NMR $\left(\mathrm{C}_{6} \mathrm{D}_{6}, 125 \mathrm{MHz}, 298 \mathrm{~K}\right) \delta(\mathrm{ppm}): 150.5\left(\mathbf{F l u}^{t} \mathrm{Bu}\right), 149.3\left(\mathbf{F l u}^{t} \mathrm{Bu}\right), 135.2$ (Ar), 134.0 (Ar), 133.5 (Ar), 133.3 (Ar), 132.4 (Ar), 131.1 (Ar), 130.5 (Flu), 129.8 (Flu), 129.7 (Flu), 127.4 (Ar), 127.0 (Ar), $126.0($ FluH), 125.8 (FluH), $125.3($ FluH), $124.5($ FluH), $121.3($ FluH), 120.4 (FluH), 105.6 (ArSi), 89.2 (FluSi), 35.4 (Flu $\left.{ }^{t} \mathbf{B u}\right), 35.4$ (Flu $\left.{ }^{t} \mathbf{B u}\right), 31.4$ (Flu $\left.{ }^{t} \mathbf{B u}\right), 31.3$ (Flu ${ }^{t} \mathbf{B u}$ ), 24.3 (ArMe), 17.8 (ArMe), 17.5 (ArMe), 17.2 (ArMe), 16.5 (ArMe), 16.2 (ArMe), 4.9 (SiMe), 4.6 (SiMe), 1.4 (SiMe) and 1.0 (SiMe). CHN Analysis (\%): expected C 63.72, H 7.27, observed C 63.72, H 7.34.

5.6 Synthesis of ${ }^{\mathrm{Me}_{2}} \mathrm{SB}\left(\mathrm{Cp}, \mathrm{I}^{*}\right) \mathrm{Zr}\left(\mathrm{CH}_{2} \mathrm{SiMe}_{3}\right)_{2}$ (3)

1.0 equivalent ${ }^{\mathrm{Me}_{2}} \mathrm{SB}\left(\mathrm{Cp}, \mathrm{I}^{*}\right) \mathrm{ZrCl}_{2}(0.200 \mathrm{~g}, 0.400 \mathrm{mmol})$ and 2.5 equivalents $\mathrm{LiCH}_{2} \mathrm{SiMe}_{3}$ $(0.096 \mathrm{~g}, 1.00 \mathrm{mmol})$ were dissolved in benzene $(40 \mathrm{~mL})$ and stirred for four days at room temperature. The solution was filtered, the solvent removed in vacuo and the resultant dark orange solid extracted with pentane $(2 \times 15 \mathrm{~mL})$. Storage of the yellow filtrate at $-34{ }^{\circ} \mathrm{C}$ yielded ${ }^{\mathrm{Me}_{2}} \mathrm{SB}\left(\mathrm{Cp}, \mathrm{I}^{*}\right) \mathrm{Zr}\left(\mathrm{CH}_{2} \mathrm{SiMe}_{3}\right)_{2}(3)$ as a yellow solid in $12 \%$ yield $(0.030 \mathrm{~g}, 0.050 \mathrm{mmol})$. ${ }^{1} \mathrm{H}$ NMR $\left(\mathrm{C}_{6} \mathrm{D}_{6}, 500 \mathrm{MHz}, 298 \mathrm{~K}\right) \delta$ (ppm): $6.90(\mathrm{CpH}, 1 \mathrm{H}, \mathrm{m}), 6.72(\mathrm{CpH}, 1 \mathrm{H}, \mathrm{m}), 5.82(\mathrm{CpH}$, 1H, m), 5.20 (CpH, 1H, m), 2.50 (ArMe, 3H, s), 2.40 (ArMe, 3H, s), 2.17 (ArMe, 3H, s), 2.11 (ArMe, 3H, s), 2.07 (ArMe, 3H, s), 1.90 (ArMe, 3H, s), 0.63 (SiMe, 3H, s), 0.62 (SiMe, 3H, s), $0.21\left(\mathrm{CH}_{2} \mathrm{SiMe}, 9 \mathrm{H}, \mathrm{s}\right), 0.08\left(\mathrm{CHSiMe}, 1 \mathrm{H}, \mathrm{d},{ }^{2} \mathrm{~J}_{\mathrm{H}-\mathrm{H}}=10 \mathrm{~Hz}\right),-0.02\left(\mathrm{CH}_{2} \mathrm{SiMe}, 9 \mathrm{H}, \mathrm{s}\right),-$ $0.52\left(\mathrm{CHSiMe}, 1 \mathrm{H}, \mathrm{d},{ }^{2} J_{\mathrm{H}-\mathrm{H}}=10 \mathrm{~Hz}\right),-1.11\left(\mathrm{CHSiMe}, 1 \mathrm{H}, \mathrm{d},{ }^{2} J_{\mathrm{H}-\mathrm{H}}=10 \mathrm{~Hz}\right)$ and -2.49 (CHSiMe, $\left.1 \mathrm{H}, \mathrm{d},{ }^{2} J_{\mathrm{H}-\mathrm{H}}=10 \mathrm{~Hz}\right) \cdot{ }^{13} \mathrm{C}\left\{{ }^{1} \mathrm{H}\right\} \mathrm{NMR}\left(\mathrm{C}_{6} \mathrm{D}_{6}, 125 \mathrm{MHz}, 298 \mathrm{~K}\right) \delta$ (ppm): 133.5 (Ar), 132.9 (Ar), 132.1 (Ar), 130.3 (Ar), 129.7 (Ar), 129.4 (Ar), 126.6 (Ar), 121.8 (Ar), 118.7 (Cp), 115.8 (Cp), 113.9 (Cp), 111.1 (Cp), 103.1 (CpSi), 79.1 (ArSi), 46.3 (CH CHiMe $_{2}$, 46.2 ( $\mathrm{CH}_{2} \mathrm{SiMe}$ ), 21.4 (ArMe), 17.4 (ArMe), 17.3 (ArMe), 16.8 (ArMe), 16.5 (ArMe), 15.7 (ArMe), 4.7 (SiMe), $4.1\left(\mathrm{CH}_{2} \mathrm{SiMe}\right), 3.6$ ( $\left.\mathrm{SiMe}\right)$ and $3.1\left(\mathrm{CH}_{2} \mathrm{SiMe}\right)$.

\subsection{Synthesis of ${ }^{\mathrm{Me}_{2}} \mathrm{SB}\left(\mathrm{Cp}^{\mathrm{Me}}, \mathrm{I}^{*}\right) \mathrm{Zr}\left(\mathrm{CH}_{2} \mathrm{SiMe}_{3}\right)_{2}$ (4)}

1.0 equivalent ${ }^{\mathrm{Me}_{2}} \mathrm{SB}\left(\mathrm{Cp}^{\mathrm{Me}}, \mathrm{I}^{*}\right) \mathrm{ZrCl}_{2}(0.204 \mathrm{~g}, 0.400 \mathrm{mmol})$ and 2.5 equivalents $\mathrm{LiCH}_{2} \mathrm{SiMe}_{3}$ $(0.0960 \mathrm{mg}, 1.00 \mathrm{mmol})$ were dissolved in benzene $(40 \mathrm{~mL})$ and stirred for four days at room temperature. The solution was filtered, the solvent removed in vacuo and the resultant dark 
orange solid extracted with pentane $(2 \times 15 \mathrm{~mL})$. Storage of the yellow filtrate at $-34{ }^{\circ} \mathrm{C}$ yielded ${ }^{\mathrm{Me}_{2}} \mathrm{SB}\left(\mathrm{Cp}^{\mathrm{Me}}, I^{*}\right) \mathrm{Zr}\left(\mathrm{CH}_{2} \mathrm{SiMe}_{3}\right)_{2}$ (4) as a yellow solid in 53\% yield $(0.132 \mathrm{~g}$, $0.220 \mathrm{mmol})$. Isomer $A$ : ${ }^{1} \mathrm{H}$ NMR $\left(\mathrm{C}_{6} \mathrm{D}_{6}, 500 \mathrm{MHz}, 298 \mathrm{~K}\right) \delta(\mathrm{ppm}): 6.46(\mathrm{CpH}, 1 \mathrm{H}, \mathrm{m}), 5.92$ (CpH, 1H, m), 4.94 (CpH, 1H, m), 2.55 (ArMe, 3H, s), 2.21 (ArMe, 6H, s), 2.38 (ArMe, 3H, s), 2.20 (ArMe, 3H, s), 2.17 (ArMe, 3H, s), 1.83 (ArMe, 3H, s), 0.64 (SiMe, 3H, s), 0.63 (SiMe, 3H, s), 0.24 (CHSiMe, 1H, d, $\left.{ }^{2} J_{\mathrm{H}-\mathrm{H}}=10 \mathrm{~Hz}\right), 0.21\left(\mathrm{CH}_{2} \mathrm{SiMe}, 9 \mathrm{H}, \mathrm{s}\right), 0.03\left(\mathrm{CH}_{2} \mathrm{SiMe}, 9 \mathrm{H}, \mathrm{s}\right)$, $-0.90\left(\mathrm{CHSiMe}, 1 \mathrm{H}, \mathrm{d},{ }^{2} J_{\mathrm{H}-\mathrm{H}}=10 \mathrm{~Hz}\right),-0.99\left(\mathrm{CHSiMe}, 1 \mathrm{H}, \mathrm{d},{ }^{2} J_{\mathrm{H}-\mathrm{H}}=10 \mathrm{~Hz}\right)$ and -2.60 (CHSiMe, 1H, d, $\left.{ }^{2} J_{\mathrm{H}-\mathrm{H}}=10 \mathrm{~Hz}\right) .{ }^{13} \mathrm{C}\left\{{ }^{1} \mathrm{H}\right\} \mathrm{NMR}\left(\mathrm{C}_{6} \mathrm{D}_{6}, 125 \mathrm{MHz}, 298 \mathrm{~K}\right) \delta(\mathrm{ppm}): 122.5$ (CpMe), 114.7 (Cp), 113.5 (Cp), 112.7 (Cp), 101.5 (CpSi), 78.6 (ArSi), $54.1\left(\mathbf{C H}_{2} \mathrm{SiMe}\right)$, $40.2\left(\mathrm{CH}_{2} \mathrm{SiMe}\right), 21.2$ (CpMe), 17.7 (ArMe), 16.8 (ArMe), 16.8 (ArMe), 16.3 (ArMe), 15.8 (ArMe), 15.5 (ArMe), 5.0 (SiMe), $3.9\left(\mathrm{CH}_{2} \mathrm{SiMe}\right), 3.7$ ( $\left.\mathrm{SiMe}\right)$ and $3.1\left(\mathrm{CH}_{2} \mathrm{SiMe}\right)$. Ar resonances cannot be further assigned to the separate isomers (133.3, 133.3, 132.9, 132.4, 132.4, 132.2, 131.9, 130.8, 129.8, 129.8, 129.6, 129.5, 129.2, 127.4, 127.0, 126.9). Isomer B: ${ }^{1} \mathrm{H}$ NMR $\left(\mathrm{C}_{6} \mathrm{D}_{6}, 500 \mathrm{MHz}, 298 \mathrm{~K}\right) \delta(\mathrm{ppm}): 6.70(\mathrm{CpH}, 1 \mathrm{H}, \mathrm{m}), 5.51(\mathrm{CpH}, 1 \mathrm{H}, \mathrm{m}), 5.22(\mathrm{CpH}$, 1H, m), 2.60 (ArMe, 3H, s), 2.48 (ArMe, 3H, s), 2.14 (ArMe, 3H, s), 2.13 (ArMe, 3H, s), 2.09 (ArMe, 6H, s), 1.98 (ArMe, 3H, s),0.69 (CHSiMe, 1H, d, ${ }^{2} J_{\mathrm{H}-\mathrm{H}}=10 \mathrm{~Hz}$ ), 0.69 (SiMe, 3H, s), 0.68 (SiMe, 3H, s), 0.24 ( $\left.\mathrm{CH}_{2} \mathrm{SiMe}, 9 \mathrm{H}, \mathrm{s}\right), 0.00$ ( $\left.\mathrm{CH}_{2} \mathrm{SiMe}, 9 \mathrm{H}, \mathrm{s}\right),-0.65$ (CHSiMe, 1H, d, $\left.{ }^{2} J_{\mathrm{H}-\mathrm{H}}=10 \mathrm{~Hz}\right),-0.79\left(\mathrm{CHSiMe}, 1 \mathrm{H}, \mathrm{d},{ }^{2} J_{\mathrm{H}-\mathrm{H}}=10 \mathrm{~Hz}\right)$ and -2.49 (CHSiMe, $1 \mathrm{H}, \mathrm{d}$, $\left.{ }^{2} J_{\mathrm{H}-\mathrm{H}}=10 \mathrm{~Hz}\right) \cdot{ }^{13} \mathrm{C}\left\{{ }^{1} \mathrm{H}\right\} \mathrm{NMR}\left(\mathrm{C}_{6} \mathrm{D}_{6}, 125 \mathrm{MHz}, 298 \mathrm{~K}\right) \delta(\mathrm{ppm}): 121.4(\mathbf{C p M e}), 118.7(\mathbf{C p})$, 117.0 (Cp), 110.5 (Cp), 102.8 (CpSi), 79.7 (ArSi), 52.7 ( $\left.\mathbf{C H}_{2} \mathrm{SiMe}\right), 40.0\left(\mathbf{C H}_{2} \mathrm{SiMe}\right), 21.7$ (ArMe), 18.2 (ArMe), 17.5 (ArMe), 17.3 (ArMe), 17.1 (ArMe), 16.1 (CpMe), 15.9 (ArMe), 4.4 (SiMe), $4.4\left(\mathrm{CH}_{2} \mathrm{SiMe}\right)$ and $3.9(\mathrm{SiMe}), 3.5\left(\mathrm{CH}_{2} \mathrm{SiMe}\right)$. Ar resonances cannot be further assigned to the separate isomers $(133.3,133.3,132.9,132.4,132.4,132.2,131.9,130.8,129.8$, 129.8, 129.6, 129.5, 129.2, 127.4, 127.0, 126.9). Isomeric Mixture: CHN Analysis (\%): expected C 48.30, H 7.37; observed C 48.37, H 7.46.

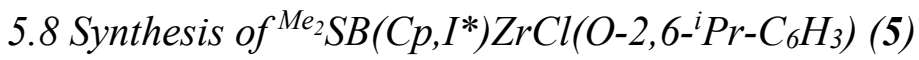

${ }^{\mathrm{Me}_{2}} \mathrm{SB}\left(\mathrm{Cp}, \mathrm{I}^{*}\right) \mathrm{ZrCl}_{2}(0.300 \mathrm{~g}, 0.620 \mathrm{mmol})$ and 2.2 equivalents $\mathrm{K}\left(\mathrm{O}-2,6-{ }^{i} \mathrm{Pr}_{-} \mathrm{C}_{6} \mathrm{H}_{3}\right)(0.296 \mathrm{~g}$, $1.37 \mathrm{mmol})$ were dissolved in benzene $(20 \mathrm{~mL})$ and stirred at room temperature for $16 \mathrm{~h}$. Filtration and removal of solvent in vacuo yielded an orange oil and the crude ${ }^{1} \mathrm{H}$ NMR spectra showed resonances corresponding to a mixture of two isomers. Extraction in pentane $(2 \times 20 \mathrm{~mL})$ and storage at $-34{ }^{\circ} \mathrm{C}$ overnight yielded a single isomer of ${ }^{\mathrm{Me}_{2}} \mathrm{SB}\left(\mathrm{Cp}, \mathrm{I}^{*}\right) \mathrm{ZrCl}\left(\mathrm{O}-2,6-{ }^{i} \mathrm{Pr}-\mathrm{C}_{6} \mathrm{H}_{3}\right)(5)$ with the aryloxide ligand positioned away from the $\mathrm{I}^{*}$ ligand ( $E$-isomer) as yellow crystals suitable for a single crystal X-ray diffraction study in $14 \%$ 
yield (0.056 g, $0.090 \mathrm{mmol})$. E-Isomer: ${ }^{1} \mathrm{H}$ NMR $\left(\mathrm{C}_{6} \mathrm{D}_{6}, 400 \mathrm{MHz}, 298 \mathrm{~K}\right) \delta(\mathrm{ppm}): 7.14$ $\left(\mathrm{OArH}, 2 \mathrm{H}, \mathrm{d},{ }^{3} J_{\mathrm{H}-\mathrm{H}}=8 \mathrm{~Hz}\right), 7.12\left(\mathrm{OArH}, 2 \mathrm{H}, \mathrm{d},{ }^{3} J_{\mathrm{H}-\mathrm{H}}=8 \mathrm{~Hz}\right), 6.99(\mathrm{OArH}, 1 \mathrm{H}, \mathrm{t}$, $\left.{ }^{3} J_{\mathrm{H}-\mathrm{H}}=8 \mathrm{~Hz}\right), 6.40(\mathrm{CpH}, 1 \mathrm{H}, \mathrm{m}), 6.26(\mathrm{CpH}, 1 \mathrm{H}, \mathrm{m}), 5.89(\mathrm{CpH}, 1 \mathrm{H}, \mathrm{m}), 5.71(\mathrm{CpH}, 1 \mathrm{H}, \mathrm{m})$, $3.61\left(\mathrm{OArCHMe}_{2}, 1 \mathrm{H}\right.$, sept, $\left.{ }^{3} J_{\mathrm{H}-\mathrm{H}}=8 \mathrm{~Hz}\right), 3.07\left(\mathrm{OArCHMe}_{2}, 1 \mathrm{H}\right.$, sept, $\left.{ }^{3} J_{\mathrm{H}-\mathrm{H}}=8 \mathrm{~Hz}\right), 2.46$ (ArMe, 3H, s), 2.31 (ArMe, 3H, s), 2.25 (ArMe, 3H, s), 2.21 (ArMe, 3H, s), 2.18 (ArMe, 3H, s), 2.15 (ArMe, 3H, s), 1.30 (OArCHMe, 12H, m), 0.77 (SiMe, 3H, s) and 0.66 (SiMe, 3H, s). ${ }^{13} \mathrm{C}\left\{{ }^{1} \mathrm{H}\right\}$ NMR $\left(\mathrm{C}_{6} \mathrm{D}_{6}, 125 \mathrm{MHz}, 298 \mathrm{~K}\right) \delta(\mathrm{ppm}): 158.9$ (OAr), 138.5 (OAr $\left.{ }^{i} \mathrm{Pr}\right), 136.9$ (Ar), 135.5 (Ar), 134.8 (OAr ${ }^{i}$ Pr), 133.9 (Ar), 133.9 (Ar), 129.7 (Ar), 129.5 (Ar), 128.2 (Ar), 126.9 (Ar), 125.1 (Cp), 123.9 (OArH), 123.8 (OArH), 120.6 (OArH), 120.1 (Cp), 120.0 (Cp) 113.1 (CpSi), 109.1 (Cp), 85.8 (ArSi), 27.4 (OArCHMe), 25.7 (OArCH), 25.3 (OArCHMe), 25.0 (OArCH), 23.7 (OArCHMe), 23.0 (OArCHMe), 21.2 (ArMe), 17.5 (ArMe), 17.4 (ArMe), 16.7 (ArMe), 16.6 (ArMe), 15.1 (ArMe), 4.4 (SiMe) and 3.2 (SiMe). Z-Isomer: ${ }^{1} \mathrm{H}$ NMR (benzene- $\left.d_{6}, 400 \mathrm{MHz}, 298 \mathrm{~K}\right) \delta(\mathrm{ppm}): 7.05(\mathrm{OArH}, 2 \mathrm{H}, \mathrm{m}), 6.83(\mathrm{OArH}, 1 \mathrm{H}, \mathrm{t}$, $\left.{ }^{3} J_{\mathrm{H}-\mathrm{H}}=8 \mathrm{~Hz}\right), 6.79(\mathrm{CpH}, 1 \mathrm{H}, \mathrm{m}), 6.19(\mathrm{CpH}, 1 \mathrm{H}, \mathrm{m}), 6.12(\mathrm{CpH}, 1 \mathrm{H}, \mathrm{m}), 5.61(\mathrm{CpH}, 1 \mathrm{H}, \mathrm{m})$, $3.56\left(\mathrm{OArCHMe}_{2}, 1 \mathrm{H}\right.$, sept, $\left.{ }^{3} J_{\mathrm{H}-\mathrm{H}}=10 \mathrm{~Hz}\right), 2.93\left(\mathrm{OArCHMe}_{2}, 1 \mathrm{H}\right.$, sept, $\left.{ }^{3} J_{\mathrm{H}-\mathrm{H}}=10 \mathrm{~Hz}\right), 2.57$ (ArMe, 3H, s) 2.42 (ArMe, 3H, s), 2.35 (ArMe, 3H, s), 1.99 (ArMe, 3H, s), 1.88 (ArMe, 3H, s), 1.66 (ArMe, 3H, s), 1.15 (OArCHMe, 12H, m), 0.85 (SiMe, 3H, s) and 0.69 (SiMe, 3H, s). CCDC number: 1958153.

\subsection{Synthesis of LDHMAO}

Toluene $(40 \mathrm{~mL})$ was added to 1.0 equivalent thermally treated $\left(150{ }^{\circ} \mathrm{C}\right.$ for 6 hours $) \mathrm{LDH}$ $\left(\mathrm{Mg}_{3} \mathrm{Al}-\mathrm{CO}_{3}\right)$ and 0.5 equivalents $\mathrm{MAO}$ and the mixture heated at $80{ }^{\circ} \mathrm{C}$ for $2 \mathrm{~h}$ with swirling. The colourless solid was allowed to settle, the solution decanted and the product dried under vacuum to give the activated support in quantitative yield.

\subsection{Synthesis of solid pre-catalysts}

Dried solid polymethylaluminoxane or LDHMAO and complex $\left(\left[\mathrm{Al}_{\text {support }}\right]_{0} /[\mathrm{Zr}]_{0}=200\right)$ were slurried in toluene $(40 \mathrm{~mL})$ and heated at $60^{\circ} \mathrm{C}$ for $1 \mathrm{~h}$ with swirling. The coloured solid was allowed to settle and the clear, colourless supernatant decanted. The solid was dried in vacuo to give the product as a faintly coloured powder in quantitative yield.

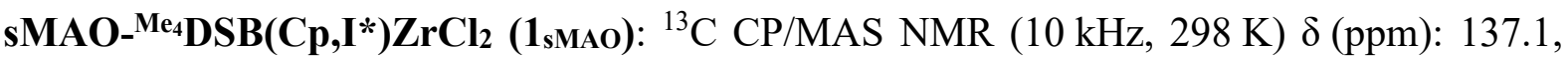
135.8, 135.3, 131.8, 128.3, 17.1, 16.0 and -7.7. ${ }^{29} \mathrm{Si} \mathrm{CP} / \mathrm{MAS}$ NMR (10 kHz, $\left.298 \mathrm{~K}\right) \delta$ (ppm): -12.7. ${ }^{27} \mathrm{Al}$ DP/MAS NMR (15 kHz, $\left.298 \mathrm{~K}\right) \delta$ (ppm): 345.8, 206.1, 71.6, -82.0 and -239.1 . 
SMAO-Me ${ }_{4} \mathbf{D S B}\left({ }^{t \mathbf{B u}_{2}} \mathbf{F l u}, \mathbf{I}^{*}\right) \mathbf{Z r C l}_{2}\left(\mathbf{2}_{\text {sMAO }}\right):{ }^{13} \mathrm{C} \mathrm{CP} / \mathrm{MAS}$ NMR $(10 \mathrm{kHz}, 298 \mathrm{~K}) \delta$ (ppm): 137.0, 128.2, 119.8, 35.2, 30.3, 15.9 and $-8.1 .{ }^{29} \mathrm{Si} \mathrm{CP} / \mathrm{MAS}$ NMR $(10 \mathrm{kHz}, 298 \mathrm{~K}) \delta(\mathrm{ppm}):-5.3$ and -20.6. ${ }^{27} \mathrm{Al} \mathrm{DP} / \mathrm{MAS}$ NMR $(15 \mathrm{kHz}, 298 \mathrm{~K}) \delta(\mathrm{ppm}): 343.8,203.3,68.2,-83.0$ and -240.0 .

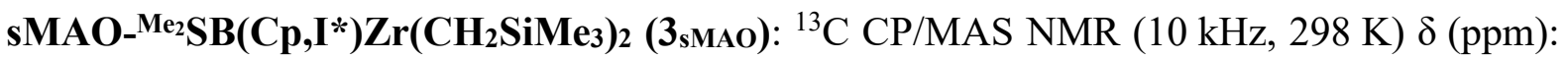
136.6, 129.5, 52.3, 17.2 and -7.8. ${ }^{29} \mathrm{Si} \mathrm{CP} / \mathrm{MAS}$ NMR (10 kHz, $\left.298 \mathrm{~K}\right) \delta(\mathrm{ppm}): 0.6$ and -11.8 . ${ }^{27} \mathrm{Al}$ DP/MAS NMR $(15 \mathrm{kHz}, 298 \mathrm{~K}) \delta(\mathrm{ppm}): 313.4,164.4,-92.7$ and -252.2 .

LDHMAO-Me2 SB(Cp,I*)Zr(CH2SiMe3)2 (3LdhMao): ${ }^{13} \mathrm{C} \mathrm{CP} / \mathrm{MAS}$ NMR (10 kHz, $\left.298 \mathrm{~K}\right)$ $\delta$ (ppm): 166.7, 131.2, 66.4, 55.3, 17.2 and -7.8. ${ }^{29} \mathrm{Si} \mathrm{CP} / \mathrm{MAS}$ NMR $(10 \mathrm{kHz}, 298 \mathrm{~K}) \delta$ (ppm): 0.8 and $-13.6 .{ }^{27} \mathrm{Al}$ DP/MAS NMR (15 kHz, $\left.298 \mathrm{~K}\right) \delta$ (ppm): 451.7, 318.4, 117.1, 18.5 and -244.4 .

\subsection{Slurry-phase ethylene polymerisation}

Scavenger $\left(\left[\mathrm{Al} l_{\text {scav }}\right]_{0} /[\mathrm{Zr}]_{0}=1000\right)$ in hexane $(10 \mathrm{~mL})$ was added to a $150 \mathrm{~mL}$ Rotaflo ampoule. The supported complex $(10 \mathrm{mg})$ was added and washed with hexane $(40 \mathrm{~mL})$. The ampoule headspace was degassed whilst heating to temperature. The ampoule was opened to ethylene gas ( 2 bar) and the solution stirred at $1000 \mathrm{rpm}$ for the duration of the run. On completion, the reaction mixture was degassed and the polymer filtered, washed with pentane $(2 \times 25 \mathrm{~mL})$ and dried under reduced pressure on a frit. All runs were carried out, at least, in duplicate.

\section{Acknowledgments}

J. V. L., J.-C. B. and Z. R. T. (SCG Research Fellowship) would like to thank SCG Chemicals Co., Ltd. (Thailand) for financial support; Dr Nicholas H. Rees (University of Oxford) for solid-state NMR spectroscopy experiments; Chemical Crystallography (University of Oxford) for the use of the diffractometers; Research Complex at Harwell for use of the Scanning Electron Microscope; Ms Liv Thobru (Norner AS, Norway) for GPC, and Prof. Charlotte Williams (University of Oxford) for use of the Differential Scanning Calorimeter.

\section{References}

1. L. Resconi, L. Cavallo, A. Fait and F. Piemontesi, Chem. Rev., 2000, 100, 1253-1346.

2. G. G. Hlatky, Chem. Rev., 2000, 100, 1347-1376. 
3. W. Kaminsky, A. Funck and H. Haehnsen, Dalton Trans., 2009, 8803-8810.

4. I. Sedov, V. Makhaev and P. E. Matkovskii, Catal. Ind., 2012, 4, 129-140.

5. P. J. Shapiro, Coord. Chem. Rev., 2002, 231, 67-81.

6. B. Wang, Coord. Chem. Rev., 2006, 250, 242-258.

7. J.-C. Buffet, Z. R. Turner and D. O'Hare, Chem. Commun., 2018, 54, 10970-10973.

8. P. Ransom, A. E. Ashley, N. D. Brown, A. L. Thompson and D. O'Hare, Organometallics, 2011, 30, 800-814.

9. J.-C. Buffet, T. A. Q. Arnold, Z. R. Turner, P. Angpanitcharoen and D. O'Hare, RSC Adv., 2015, 5, 87456-87464.

10. H. G. Alt and A. Koppl, Chem. Rev., 2000, 100, 1205-1221.

11. G. Tian, B. Wang, S. Xu, Y. Zhang and X. Zhou, J. Organomet. Chem., 1999, 579, 24-29.

12. C. Copéret and J.-M. Basset, Adv. Synth. Catal., 2007, 349, 78-92.

13. C. Copéret, F. Allouche, K. W. Chan, M. P. Conley, M. F. Delley, A. Fedorov, I. B. Moroz, V. Mougel, M. Pucino, K. Searles, K. Yamamoto and P. A. Zhizhko, Angew. Chem., Int. Ed., 2018, 57, 6398-6440.

14. J. D. A. Pelletier and J.-M. Basset, Acc. Chem. Res., 2016, 49, 664-677.

15. C. Copéret, A. Fedorov and P. A. Zhizhko, Catal. Lett., 2017, 147, 2247-2259.

16. C. Copéret, A. Comas-Vives, M. P. Conley, D. P. Estes, A. Fedorov, V. Mougel, H. Nagae, F. Nunez-Zarur and P. A. Zhizhko, Chem. Rev., 2016, 116, 323-421.

17. C. Copéret, M. Chabanas, R. P. Saint-Arroman and J.-M. Basset, Angew. Chem., Int. Ed., 2003, 42, 156-181.

18. R. Anwander, Chem. Mater., 2001, 13, 4419-4438.

19. P. Serna and B. C. Gates, Acc. Chem. Res., 2014, 47, 2612-2620.

20. M. K. Samantaray, E. Pump, A. Bendjeriou-Sedjerari, V. D'Elia, J. D. A. Pelletier, M. Guidotti, R. Psaro and J.-M. Basset, Chem. Soc. Rev., 2018, 47, 8403-8437.

21. J. A. Ewen, J. Am. Chem. Soc., 1984, 106, 6355-6364.

22. J. A. Ewen, R. L. Jones, A. Razavi and J. D. Ferrara, J. Am. Chem. Soc., 1988, 110, 6255-6256.

23. V. F. Tisse, F. Prades, R. Briquel, C. Boisson and T. F. L. McKenna, Macromol. Chem. Phys., 2010, 211, 91-102.

24. A. Entezami and P. N. Moghadam, Polym. Int., 2005, 54, 1326-1329.

25. J. R. Severn, J. C. Chadwick, R. Duchateau and N. Friederichs, Chem. Rev., 2005, 105, 40734147.

26. K. Soga and M. Kaminaka, Macromol. Chem. Phys., 1993, 194, 1745-1755.

27. S. Collins, W. M. Kelly and D. A. Holden, Macromolecules, 1992, 25, 1780-1785.

28. M. M. Stalzer, M. Delferro and T. J. Marks, Catal. Lett., 2015, 145, 3-14.

29. C. P. Nicholas, H. Ahn and T. J. Marks, J. Am. Chem. Soc., 2003, 125, 4325-4331.

30. M. P. McDaniel, M. D. Jensen, K. Jayaratne, K. S. Collins, E. A. Benham, N. D. McDaniel, P. K. Das, J. L. Martin, Q. Yang, M. G. Thorn and A. P. Masino, in Tailor-Made Polymers, eds. J. R. 
Severn and J. C. Chadwick, Wiley-VCH, Verlag GmbH \& Co. KGaA, Weinheim, 2008, pp. 171210.

31. T. A. Q. Arnold, Z. R. Turner, J.-C. Buffet and D. O'Hare, J. Organomet. Chem., 2016, 822, 8590.

32. D. A. X. Fraser, Z. R. Turner, J.-C. Buffet and D. O'Hare, Organometallics, 2016, 35, 2664-2674.

33. T. J. Williams, J.-C. Buffet, Z. R. Turner and D. O'Hare, Catal. Sci. Technol., 2018, 8, 5454-5461.

34. I. I. Zakharov, V. A. Zakharov, A. G. Potapov and G. M. Zhidomirov, Macromol. Theory Simul., 1999, 8, 272-278.

35. J. V. Lamb, J.-C. Buffet, Z. R. Turner and D. O'Hare, Polym. Chem., 2019, 10, 1386-1398.

36. J. V. Lamb, J.-C. Buffet, J. E. Matley, C. M. R. Wright, Z. R. Turner and D. O'Hare, Dalton Trans., $2019,48,2510-2520$.

37. S. Gutmann, P. Burger, H.-U. Hund, J. Hofmann and H.-H. Brintzinger, J. Organomet. Chem., 1989, 369, 343-357.

38. O. Perez-Camacho, S. Y. Knjazhanski, G. Cadenas, M. J. Rosales-Hoz and M. A. Leyva, J. Organomet. Chem., 1999, 585, 18-25.

39. A. V. Firth, J. C. Stewart, A. J. Hoskin and D. W. Douglas, J. Organomet. Chem., 1999, 591, 185193.

40. W. A. Howard, T. M. Trnka and G. Parkin, Inorg. Chem., 1995, 34, 5900-5909.

41. N. Senso, S. Khaubunsongserm, B. Jongsomjit and P. Praserthdam, Molecules, 2010, 15, 93239339.

42. H. Hammawa, T. M. Mannan, D. T. Lynch and S. E. Wanke, J. Appl. Polym. Sci., 2004, 92, 35493560 .

43. D. T. Lynch, M. O. Jejelowo and S. E. Wanke, Can. J. Chem. Eng., 1991, 69, 657-664.

44. N. V. Semikolenova and V. A. Zakharov, 1997, 198, 2889-2897.

45. J. T. Hirvi, M. Bochmann, J. R. Severn and M. Linnolahti, ChemPhysChem, 2014, 15, 2732-2742.

46. F. Q. Song, R. D. Cannon and M. Bochmann, J. Am. Chem. Soc., 2003, 125, 7641-7653.

47. M. Bochmann and S. J. Lancaster, Angew. Chem., Int. Ed., 1994, 33, 1634-1637.

48. V. F. Tisse, C. Boisson and T. F. L. McKenna, Macromol. Chem. Phys., 2014, 215, 1358-1369.

49. W. Michiels and A. Munozescalona, Macromol. Symp., 1995, 97, 171-183.

50. J. E. O'Hara and K. B. Wagener, Makromol. Chem., Rapid Commun., 1993, 14, 657-662.

51. G. Rojas, B. Inci, Y. Wei and K. B. Wagener, J. Am. Chem. Soc., 2009, 131, 17376-17386.

52. A. S. Vaughan and D. C. Bassett, in Comprehensive Polymer Science and Supplements, eds. G. Allen and J. C. Bevington, Pergamon, Amsterdam, 1989, pp. 415-457.

53. C. F. Luo, M. Kroger and J. U. Sommer, Polymer, 2017, 109, 71-84.

54. C. B. Crawford and B. Quinn, in Microplastic Pollutants, eds. C. B. Crawford and B. Quinn, Elsevier, 2017, pp. 57-100.

55. T. Repo, G. Jany, M. Salo, M. Polamo and M. Leskela, J. Organomet. Chem., 1997, 541, 363366.

56. C. M. R. Wright, Z. R. Turner, J.-C. Buffet and D. O'Hare, Chem. Commun., 2016, 52, 2850-2853. 
57. A. Macchioni, Chem. Rev., 2005, 105, 2039-2074.

58. E. Zurek and T. Ziegler, Organometallics, 2002, 21, 83-92.

59. E. Zurek and T. Ziegler, Prog. Polym. Sci., 2004, 29, 107-148.

60. M. A. Parvez, M. Rahaman, M. A. Suleiman, J. B. P. Soares and I. A. Hussein, Int. J. Polym. Sci., 2014, 1-10.

61. L. D 'Agnillo, J. B. P. Soares and A. Penlidis, Macromol. Chem. Phys., 1998, 199, 955-962.

62. M. D. F. V. Marques and R. B. Tiosso, J. Mater. Sci. Eng. Adv. Tech., 2011, 4, 149-173.

63. J.-C. Buffet, N. Wanna, T. A. Q. Arnold, E. K. Gibson, P. P. Wells, Q. Wang, J. Tantirungrotechai and D. O'Hare, Chem. Mater., 2015, 27, 1495-1501.

64. J.-C. Buffet, Z. R. Turner, R. T. Cooper and D. O'Hare, Polym. Chem., 2015, 6, 2493-2503.

65. C. Chen, M. Yang, Q. Wang, J.-C. Buffet and D. O'Hare, J. Mater. Chem. A., 2014, 2, 1510215110.

66. Q. Wang and D. O'Hare, Chem. Commun., 2013, 49, 6301-6303. 